\title{
Evaluation of Electrochemical Ion Exchange for Cesium Elution
}

\author{
J. D. Bontha \\ D. E. Kurath \\ J. E. Surma \\ M. F. Buehler
}

April 1996

Prepared for

the U.S. Department of Energy

under Contract DE-AC06-76RLO 1830

Pacific Northwest National Laboratory

Richland, Washington 99352 
PNNL-11125

UC-810

Project Technical Information

\title{
Evaluation of Electrochemical Ion Exchange for Cesium Elution
}

\author{
JR Bontha \\ DE Kurath \\ JE Surma \\ MF Buehler
}

April 1996

Prepared for

the U.S. Department of Energy

under Contract DE-AC06-76RLO 1830

Pacific Northwest National Laboratory

Richland, Washington 99352 


\section{DISCLAIMER}

This report was prepared as an account of work sponsored by an agency of the United States Government. Neither the United States Government nor any agency thereof, nor Battelle Memorial Institute, nor any of their employees, makes any warranty, express or implied, or assumes any legal liability or responsibility for the accuracy, completeness, or.usefulness of any information, apparatus, product, or process disclosed, or represents that its use would not infringe privately owned rights. Reference herein to any speciric commercial product, process, or service by trade name, trademark, manufacturer, or othenvise does not necessarily constitute or imply its endorsement, recommendation, or favoring by the United States Government or any agency thereof, or Battelle Memorial institute. The views and opinions of authors expressed herein do not necessarily state or reflect those of the United States Government or any agency thereof.

\section{PACIFIC NORTHWEST NATIONAL LABORATORY operated by BATTELLE for the UNITED STATES DEPARTMENT OF ENERGY under Contract DE-AC06-76RLO 1830}

Printed in the United Stales of America

Available to DOE and DOE contractors from the

Office of Scientific and Tecinical Information, P.O. Box 62, Oak Ridge, TN 37831; prices available from (615) 576-8401.

Available to the public from the National Technical Information Service, U.S. Department of Commerce, 5285 Port Royal Rd., Springfield, VA 22161 


\section{SUMMARY}

Electrochemical elution was investigated as an alternative method to acid elution for the desorption of cesium from loaded.ion exchange resins. The approach was found to have several potential advantages over existing technologies, in particular, electrochemical elution eliminates the need for addition of chemicals to elute cesium from the ion exchange resin. Also, since, in the electrochemical elution process the eluting solution is not in direct contact with the ion exchange material, very small volumes of the eluting solution can be used in a complete recycle mode in order to minimize the total volume of the cesium eluate. In addition, the cesium is eluted as an alkaline solution that doesnot require neutralization with caustic to meet the tank farm specifications. Other advantages include easy incorporation of the electrochemical elution process into the present cesium recovery schemes.

The electrochemical ion exchange process evaluation was performed by researchers at PNL using the CS-100 ion exchange resin and by a subcontract with AEA Technology (formerly the Atomic Energy Agency of the United Kingdom) using resorcinol formaldehyde and Lewitat DN-KR ion exchange resins. Lewitat DN-KR is a phenol formaldehyde resin similar to CS-100 and was used in place of CS-100 because of the shortage of availability of the CS-100 ion exchange resin. The most significant result of the investigation was that extremely low volumes of the elution solutions ( $<10$ Bed Volumes) can be used to completely elute the absorbed cesium. Comparing with the conventional acid elution techniques using cesium loaded resorcinol formaldehyde resin, this was found to corresponded to a reduction of about $70 \%$ in the total waste volume generated. Also, since the eluting solution is not in direct contact with the ion exchange resin and since the electrical driving force on the eluted cations opposes back migration, the results of the present evaluation indicate that in the electrochemical elution processes eluting solution volumes as low as $2.5 \mathrm{BV}$ (Bed Volumes) as there was no reabsorption of the eluted cesium back onto the resin.

Two equipment configurations were studied for the evaluation of the electrochemical elution process. The first consists of the ion exchange resin made into a foam using binders such as butadiene and polystyrene. In the second configuration, the ion exchange material is used as a packed bed. The former is often referred to as the EIX configuration and the later is termed as the 
$\mathrm{ED} / \mathrm{LX}$ configuration. The primary difference observed between EDX and ED/IX was in the electrical conductivity of the un-bonded resin in the ED/IX configuration and the bonded resin in the EIX configuration. In the case of EIX, as the resin particles are in intimate contact with each other, the electrical resistance across the cell was found to be less. than that in the ED/IX mode of operation were the resin particles are loosely packed. The EIX mode, however, was found to suffer from the disadvantage of having relatively small amounts of the ion exchange resin for the same volume of the bed in the ED/IX mode because binders such as butadiene are added to the former to create the ion exchange foam. Improvement in the applied current for the ED/IX mode of operation were achieved by using two cation exchange membranes to support the ion exchange resin as opposed to an anion exchange and a cation exchange membrane.

The results of the testing in both the EIX and ED/IX mode of operation indicate that the RF resin outperforms the Lewitat $D N-K R$ resin. Also, improvements in the cesium recovery efficiency were observed with increasing the applied current and the elution period. The experimental results also indicate that because of the use of the binder in the EIX configuration, the cesium decontamination factors were extremely low (on the order of 7 to 10) as compared to the ED/LX configuration where the decontamination factors as high of $10^{4}$ were obtained with the RF resin. The results of the evaluation indicate that the electrochemical elution process using the ED/IX configuration is extremely efficient in eluting all of the cesium from the bed while using a minimum volume of the eluting solutions. 
SUMMARY $\ldots \ldots \ldots \ldots \ldots \ldots \ldots \ldots \ldots \ldots \ldots \ldots \ldots \ldots \ldots \ldots \ldots \ldots \ldots$

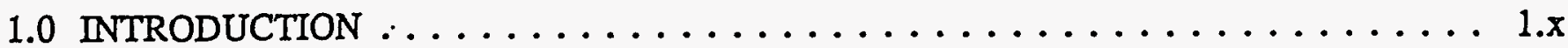

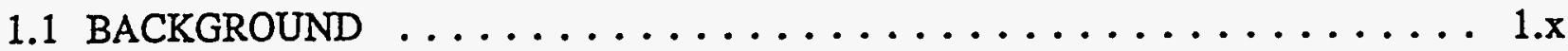

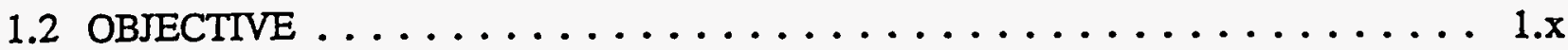

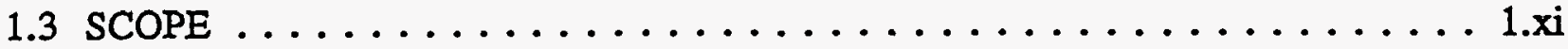

1.4 APPROACH $\ldots \ldots \ldots \ldots \ldots \ldots \ldots \ldots \ldots \ldots \ldots \ldots \ldots \ldots \ldots \ldots \ldots \ldots \ldots \ldots$

2.0 ELECTROCHEMICAL ION EXCHANGE FUNDAMENTALS $\ldots \ldots \ldots \ldots \ldots . . \ldots$

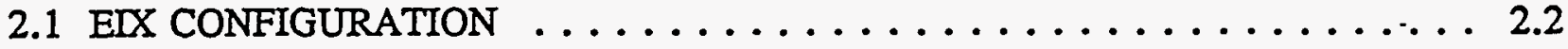

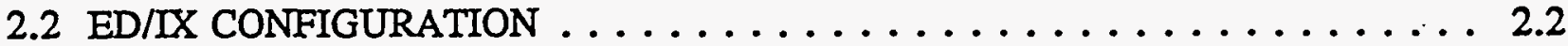

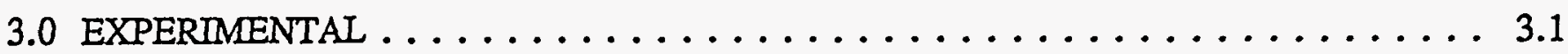

3.1 ION EXCHANGER SELECTION $\ldots \ldots \ldots \ldots \ldots \ldots \ldots \ldots \ldots \ldots \ldots \ldots$

3.2 CHEMICAL STABILITY TESTS $\ldots \ldots \ldots \ldots \ldots \ldots \ldots \ldots \ldots \ldots . \ldots \ldots$

3.3 BATCH EQUILIBRIUM EXPERIMENTS $\ldots \ldots \ldots \ldots \ldots \ldots \ldots \ldots \ldots .2$

3.4 PREPARATION OF EIX FOAMS $\ldots \ldots \ldots \ldots \ldots \ldots \ldots \ldots \ldots \ldots . \ldots \ldots$

3.4.1 Preparation of the Microporous Structure $\ldots \ldots \ldots \ldots \ldots \ldots \ldots .2$

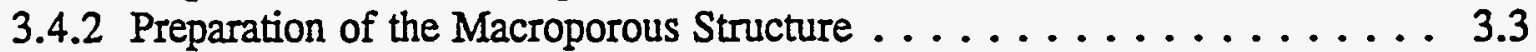

3.5 EQUIPMENT DESCRIPTION $\ldots \ldots \ldots \ldots \ldots \ldots \ldots \ldots \ldots \ldots \ldots \ldots . \ldots \ldots$

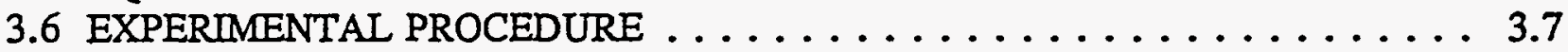

3.6 .1 Passive Loading $\ldots \ldots \ldots \ldots \ldots \ldots \ldots \ldots \ldots \ldots \ldots \ldots$

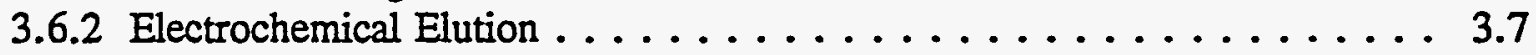

3.6 .3 Acid Elution $\ldots \ldots \ldots \ldots \ldots \ldots \ldots \ldots \ldots \ldots \ldots \ldots \ldots \ldots$

3.7 ANALYSIS AND CALCULATIONS $\ldots \ldots \ldots \ldots \ldots \ldots \ldots \ldots \ldots$

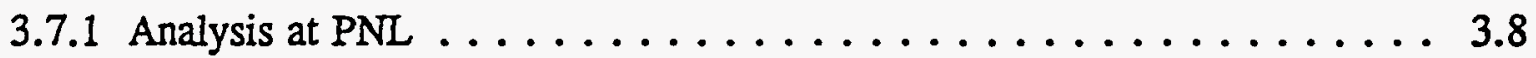

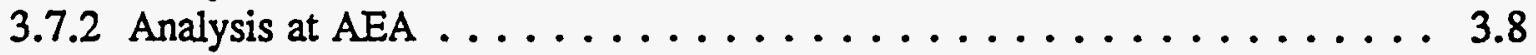

3.8 PREPARATION OF NCAW SIMULANT $\ldots \ldots \ldots \ldots \ldots \ldots \ldots \ldots \ldots$

4.0 RESULTS AND DISCUSSION $\ldots \ldots \ldots \ldots \ldots \ldots \ldots \ldots \ldots \ldots \ldots \ldots \ldots \ldots$

4.1 EFFECT OF BINDER ON EXCHANGER LOADING . . . . . . . . . . 4.1

4.2 EFFECT OF APPLIED CURRENT AND ELUTION PERIOD . . . . . . . 4.5

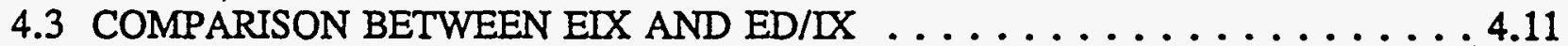

4.4 EFFECT OF EXTERNAL SODIUM CONCENTRATION . . . . . . . 4.11

4.5 COMPARISON WITH ACD ELUTION PROCESS . . . . . . . . . . 4.12

4.6 EFFECT OF THE VOLUME OF THE CATHOLYTE . . . . . . . . . . 4.14

5.0 CONCEPTUAL FLOW DESIGN $\ldots \ldots \ldots \ldots \ldots \ldots \ldots \ldots \ldots \ldots \ldots \ldots$

6.0 CONCLUSIONS $\ldots \ldots \ldots \ldots \ldots \ldots \ldots \ldots \ldots \ldots \ldots \ldots \ldots \ldots \ldots \ldots \ldots$ 


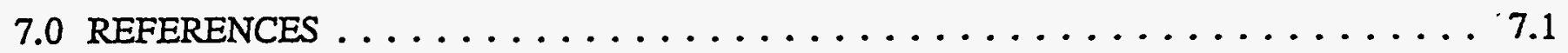

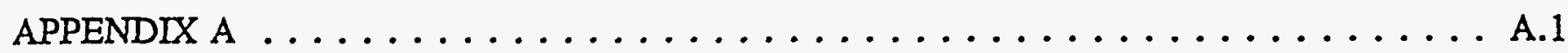

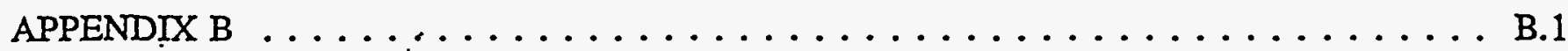

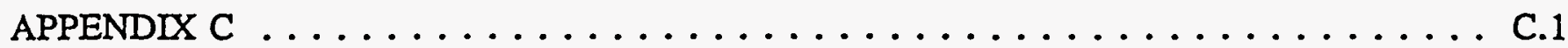




\section{FIGURES}

2.2 Schematic of a ED/IX Cell with Schematic of a ED/LX Cell With a Cation Exchange and an Anion Exchange Membrane Supporting the Resin. . . . . . . . . . . . . . . 2.4

2.3 Schematic of a ED/IX Cell With Two Cation Exchange Membranes Supporting the Resin. 2.5

3.1 A Schematic of the Electrochemical Elution Test Cell Setup . . . . . . . . . . . . 3.6

4.1 Cesium Loading Characteristics of the Resin in the EIX and ED/IX Mode of Operation. $\mathrm{T}=50^{\circ} \mathrm{C}$; Column Vol. $=100$ mils; $\mathrm{Na} / \mathrm{Cs}$ in Feed $=10,000 ;$ and Feed flowrate $=$

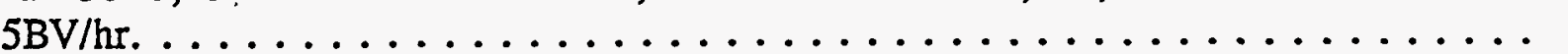

4.2 Sodium loading characteristics of the resin in the EDX and ED/IX mode of operation. $\mathrm{T}=50^{\circ} \mathrm{C}$; Column Vol. $=100 \mathrm{mils} ; \mathrm{Na} / \mathrm{Cs}$ in Feed $=10,000$; and Feed flowrate $=$

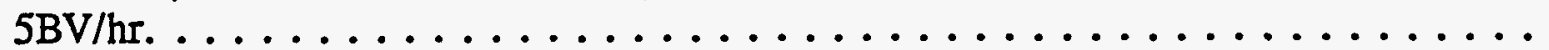

4.3 Effect of applied current on the cesium recovery efficiency during the EDX mode of . operation. $\mathrm{T}=50^{\circ} \mathrm{C}$; Column Volume $=100 \mathrm{mils}, \mathrm{Na} / \mathrm{Cs}$ in Feed $=10,000$; Feed Flowrate $=5 \mathrm{BV} / \mathrm{hr} ;$ and Cathode and Anode Area $=40 \mathrm{~cm}^{2}$.

4.4 Effect of applied current on cesium recovery efficiency during ED/LX mode of elution. $\mathrm{T}=50^{\circ} \mathrm{C}$; Column Volume $=100 \mathrm{mils}, \mathrm{Na} / \mathrm{Cs}$ in Feed $=10,000$; Feed Flowrate $=$ $5 \mathrm{BV} / \mathrm{hr}$; and Cathode and Anode Area $=40 \mathrm{~cm}^{2} . \ldots \ldots \ldots . \ldots$

4.5 Effect of increasing the elution period on the cesium recovery efficiency during EIX mode of elution. $\mathrm{T}=50^{\circ} \mathrm{C}$; Column Volume $=100 \mathrm{mils}, \mathrm{Na} / \mathrm{Cs}$ in Feed $=10,000$; Feed Flowrate $=5 B V / h r ;$ and Cathode and Anode Area $=40 \mathrm{~cm}^{2}$.

4.6 Effect of increasing the elution period on cesium recovery efficiency during EIX mode of elution. $\mathrm{T}=50^{\circ} \mathrm{C}$; Column Volume $=100 \mathrm{mils}, \mathrm{Na} / \mathrm{Cs}$ in Feed $=10,000$; Feed Flowrate $=5 \mathrm{BV} / \mathrm{hr} ;$ and Cathode and Anode Area $=40 \mathrm{~cm}^{2} . \ldots \ldots \ldots . \ldots . . . . . .4 .10$

4.7 Effect of Sodium ion concentration of the cesium recovery efficiency. $\mathrm{T}=50^{\circ} \mathrm{C}$; Column Volume $=100 \mathrm{mils}, \mathrm{Na} / \mathrm{Cs}$ in Feed $=10,000 ;$ Feed Flowrate $=5 \mathrm{BV} / \mathrm{hr}$; and Cathode and Anode Area $=40 \mathrm{~cm}^{2}$.

4.8 Typical Loading Curve for NCAW Simulant and Resorcinol Formaldehyde Resin. $\mathrm{T}=50^{\circ} \mathrm{C}$; Column Volume $=100$ mils, and Feed Flowrate $=5 B V / h r . \ldots \ldots \ldots . \ldots . . . .46$

4.9 Typical Electrochemical Elution of Cesium as a Function of Time. $\mathrm{T}=50^{\circ} \mathrm{C}$; Column Volume $=100$ mils, Cathode and Anode Area $=40 \mathrm{~cm}^{2}$; Applied Current $=2000 \mathrm{~mA} .4 .17$

4.10 Cesium Loading Curves for CS-100 Ion Exchanger. NCAW Feed; $\mathrm{T}=25^{\circ} \mathrm{C}$; Column Volume $=80$ mils; and Feed Flowrate $=16$ BV $/ \mathrm{hr} . \ldots \ldots \ldots \ldots . \ldots \ldots$

4.11 Cesium Elution From CS-100 Ion Exchanger as a Function of Time. Cathode and Anode Area $=40 \mathrm{~cm}^{2}$; and Applied Current $=900 \mathrm{~mA} . \ldots \ldots \ldots \ldots . \ldots . \ldots . . \ldots$

5.1 Conceptual Flow Diagram for the incorporation of the Electrochemical Elution into Conventional Multi-Column Configuration.

A1 Sodium Elution Curves for Lewitat DN-KR Ion Exchange Resin. : Predegradation;

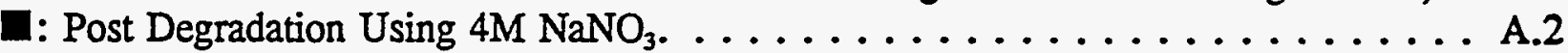

A2 Sodium Elution Curves for Lewitat DN-KR Ion Exchange Resin. : Pre-degradation; $\mathbb{Z}$ :

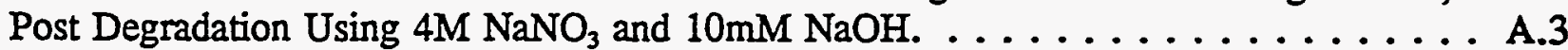

A3 Sodium Elution Curves for Lewitat DN-KR Ion Exchange Resin. O: Pre-degradation; $\mathbf{a}$ : Post Degradation Using $4 \mathrm{M} \mathrm{NaNO}_{3}$ and $100 \mathrm{mM} \mathrm{NaOH} . \ldots . . . . . . . . . . .4 .4$ 
A4 Sodium elution curves for Lewitat DN-KR ion exchange resin. - : Pre-degradation; Post- Degradation using $4 \mathrm{M} \mathrm{NaNO}_{3}$ and $1 \mathrm{M} \mathrm{NaOH} . \ldots \ldots \ldots \ldots \ldots \ldots \ldots . \ldots \ldots$

B1 Typical Counter Calibration Curve for the Analysis of ${ }^{137} \mathrm{Cs} \ldots \ldots \ldots \ldots \ldots$. . . . . . 


\section{TABLES}

1 Typical Constituents and Their Weights Taken for the Preparation of the NCAW Simulank.10 C1 Kd Values for Lewitat DN-KR and Resorcinol Formaldehyde BSC-210 Resins. . . . . C.1 


\subsection{INTRODUCTION}

\subsection{BACKGROUND}

Conventional regenerative ion exchange relies on the use of acid or base streams to elute the absorbed ions from the spent or loaded ion exchange resins. For example, at Hanford, the baseline cesium ion recovery process by cation exchange uses solutions of formic or nitric acid to elute the absorbed cesium ions from the ion exchange resin. Electrochemical elution is an advanced separation process where the ion exchange is controlled by an applied potential. Electrochemical elution is an alternative process for the regeneration of spent ion exchange resins as the acid needed for the elution is produced in situ by the electrolytic dissociation of water. Electrochemical ion exchange processes are currently being applied in the nuclear industry where it is essential to not only remove the radioactive constituents but also reduce the volume of the waste generated. Other areas of electrochemical ion exchange application include: (1) removal of toxic heavy metal ions (2) recovery of precious metals, (3) water deionization, (4) corrosive anion removal, and (5) nitrate removal.

The electrochemical ion exchange process was successfully tested to remove radioactive cesium from spent ion exchange resins at the Canadian Deuterium Uranium (CANDU) Pressurized Heavy Water Reactors (Nott, 1983). Using the electrochemical ion exchange process for cesium removal, the authors reported that the total volume of the waste was reduced by a factors of $33 \%$. Electrochemical ion exchange using zirconium phosphate as the ion exchange material was also used successfully to remove radioactive cobalt from process streams (Adams and Hudson, 1991; Bridger et al., 1991). Other applications of electrochemical ion exchange processes has.been focussed on the production of ultrapure water for semiconductor applications (Wilkins and McConnelee, 1988; Parise et al., 1990).

\subsection{OBJECTTVE}

The objective of this study was to evaluate the electrochemical elution as an alternative process to conventional acid elution for the removal of cesium from loaded (spent) ion exchange resins. The purpose of the study was to make a preliminary assessment to determine if 
electrochemical ion exchange offers benefits over conventional elution processes. Potential benefits of the electrochemical elution process includes minimization of the chemicals needed for the elution of cesium from the ion exchange resin; reduction in the volumes of the waste generated, and elimination of the safety concerns associated with the transport, storage, and handling of eluants.

\subsection{SCOPE}

The goals of the study are to make a recommendation on the use of the electrochemical ion exchange method of elution. The evaluation of electrochemical process for cesium elution from spent ion exchange material was performed by researchers at PNL and also by a subcontractor. The evaluation includes developing preliminary flow diagrams for Cs removal from a typical Hanford supernate such as Neutralized Acid Current Waste (NCAW). Care was taken in order to ensure that there is no overlap in experiments being performed at PNL and at the subcontractor's facility.

\subsection{APPROACH}

Bench scale testing using cesium selective ion exchange materials was conducted by AEA Technology (formerly the Atomic Energy Authority of United Kingdom). Two resin configurations were tested by AEA Technology. The first configuration is based on the conventional electrochemical ion exchange (or EIX) approach. The second configuration combines the electrodialysis (ED) and ion exchange (IX), thereby referred to as ED/IX. In the EIX scheme the ion exchange material is made into a foam by adding binders such as butadiene to the resin whereas in the ED/IX approach the resin is used as received (i.e.,without any added binders). The EDX and ED/IX configurations were tested using resorcinol formaldehyde (RF) and Lewitat DN-KR ion exchange resins. Lewitat $D N-K R$ is a phenol formaldehyde ion exchange resin which was substituted in place of CS-100 ion exchange resin due to the shortage of availability of the CS-100 ion exchange resin. Experimental evaluation at AEA Technology included preparation of EIX foams from the resins (using both RF and Lewitat), process parameter optimization by performing EIX and ED/IX elutions at different current densities and different elution periods. Since Lewitat DN-KR is a previously untested material, chemical stability tests and batch equilibrium experiments (with NCAW simulant) were performed in order to determine the stability of the resin when exposed to 
high sodium solutions and to compare the distribution coefficients with the already existing data for the RF resin. Distribution coefficients for RF resin using NCAW waste simulant were also determined in order to ensure that the resin samples sent to AEA were of the same quality as those tested here at PNL. In all experiments the ion exchange resins were loaded passively (i.e., no applied voltage) and then electrochemically eluted. Testing of the electrochemical elution process using CS-100 resin were also performed (in the sandwiched bed or ED/LX configuration) by researchers at PNL. The emphasis of the work done at PNL was to optimize on the volume of the cesium treated effluent. 


\subsection{ELECTROCHEMTCAL ION EXCHANGE FUNDAMENTALS}

In the electrochemical ion exchange process, resin regeneration occurs via the acid generated at the anode by the electrolytic dissociation of water. The reactions occurring at the anode and the ion exchange resin are

$$
\text { Anode: } 2 \mathrm{H}_{2} \mathrm{O} \rightarrow \mathrm{O}_{2}+4 \mathrm{H}^{+}+4 e^{-}
$$

$$
\text { Ion Exchange Resin: } R \cdot M+H^{+} \rightarrow R \cdot H+M^{+}
$$

Since all electrochemical reactions involve anodic and cathodic reactions occurring simultaneously at the anode and the cathode surfaces, the reaction occurring at the cathode involves the unwanted generation of a hydroxide stream as shown below

$$
\text { Cathode: } \mathrm{H}_{2} \mathrm{O}+e^{-} \rightarrow \mathrm{H}_{\text {ads }}+\mathrm{OH}^{-}
$$

The base generation is an unwanted side reaction since it could combine with the acid generated at the anode and reduce the efficiency of the metal ion elution. Electrochemical ion exchange cells are therefore designed in such a manner that they minimize combination of the electrochemically generated acid and base via the use of ion exchange membranes to prevent the transport of the unwanted ionic species.

In the electrochemical elution process, the spent ion exchange resin is either (1) modified into a macroporous foam by the addition of binders such as polystyrene and polybutadiene or (2) used as received (i.e., without the addition of binders). The former is often referred to as the EIX process while the later is referred to as the ED/IX process. The two resin configurations are described below. 


\subsection{EIX CONFIGURATION}

In the EIX configuration, the cesium selective ion exchanger is modified into a macroporous foam and then attached to a microporous cation exchange material (which is non-cesium selective) as shown in Figure 2.1. The microporous structure is also referred to as the EIX membrane. The microporous structures are typically manufactured from strong acid cation exchangers which will pass any cations but not anions under the application of an electric field. The function of this microporous material is (1) to eliminate the hydroxide ions generated at the cathode compartment and neutralizing the acid, (2) improve the electrical conductivity of the system, and (3) prevent the eluted cesium from reabsorbing into the ion exchanger. During the elution cycle, protons generated at the anode migrate through the microporous structure into the macroporous cesium selective ion exchanger (RF or Lewitat foam in the present study). The cesium and other ions on the resin are displaced by the incoming protons and migrate through the other microporous structure into the catholyte compartment. No chemicals are needed during this elution as the electrical conductivity of the microporous and macroporous structures are sufficiently high to pass significant currents to elute the resin. Therefore, cathode and anode compartments can be filled with deionized water. Also, in the EIX elution mode, the anolyte is continuously recirculated with periodic addition of deionized water to replace the water lost as hydration sheath on the eluting protons and due to some water seepage. The catholyte solution is continuously drained as volume increases as a result of the water transported from the anolyte compartment (as hydration sheath of the eluting ions and also due to water seepage across the micro- and macroporous structures).

\subsection{ED/IX CONEIGURATION}

In the ED/IX mode, the cesium selective ion exchange material (without the addition of any binders as in $\mathrm{ELX}$ ) is suspended between a cation exchange membrane and an anion exchange membrane as in conventional electrodialysis (ED) and ion exchange (IX). A schematic of the ED/LX cell configuration is shown in Figure 2.2. In the ED/IX mode, protons, generated by the water splitting reaction at and also by proton transport across the anion exchange membrane (since most anion exchange membranes are generally poor proton excluders), elute the sodium and cesium from the ion exchange resin. The eluted cations migrate under the influence of the electric field into the 
cathode compartment. Due the low electrical conductivity of the ion exchange resin, weak acid solutions are required in the anolyte and catholyte streams. Because of the significantly less water transport of the ion exchange membranes in the ED/IX mode as compared to the water transport of the microporous structure of the EIX mode, the catholyte and anolyte solutions were continuously circulated in the ED/IX mode as opposed to draining the catholyte solution. Instead of the anion exchange membrane, resin, cation exchange membrane (AResinC) configuration, it is also possible to use replace the anion exchange membrane with a cation exchange membrane (CResinC configuration) as shown in Figure 2.3. In the CResinC configuration, the protons generated at the cathode rather than those generated by water splitting reaction at the anion exchange membrane elute the resin. As will be discussed later, the advantages of the CResinC configuration over the AResinC configuration is an increase in the limiting current of operation. 


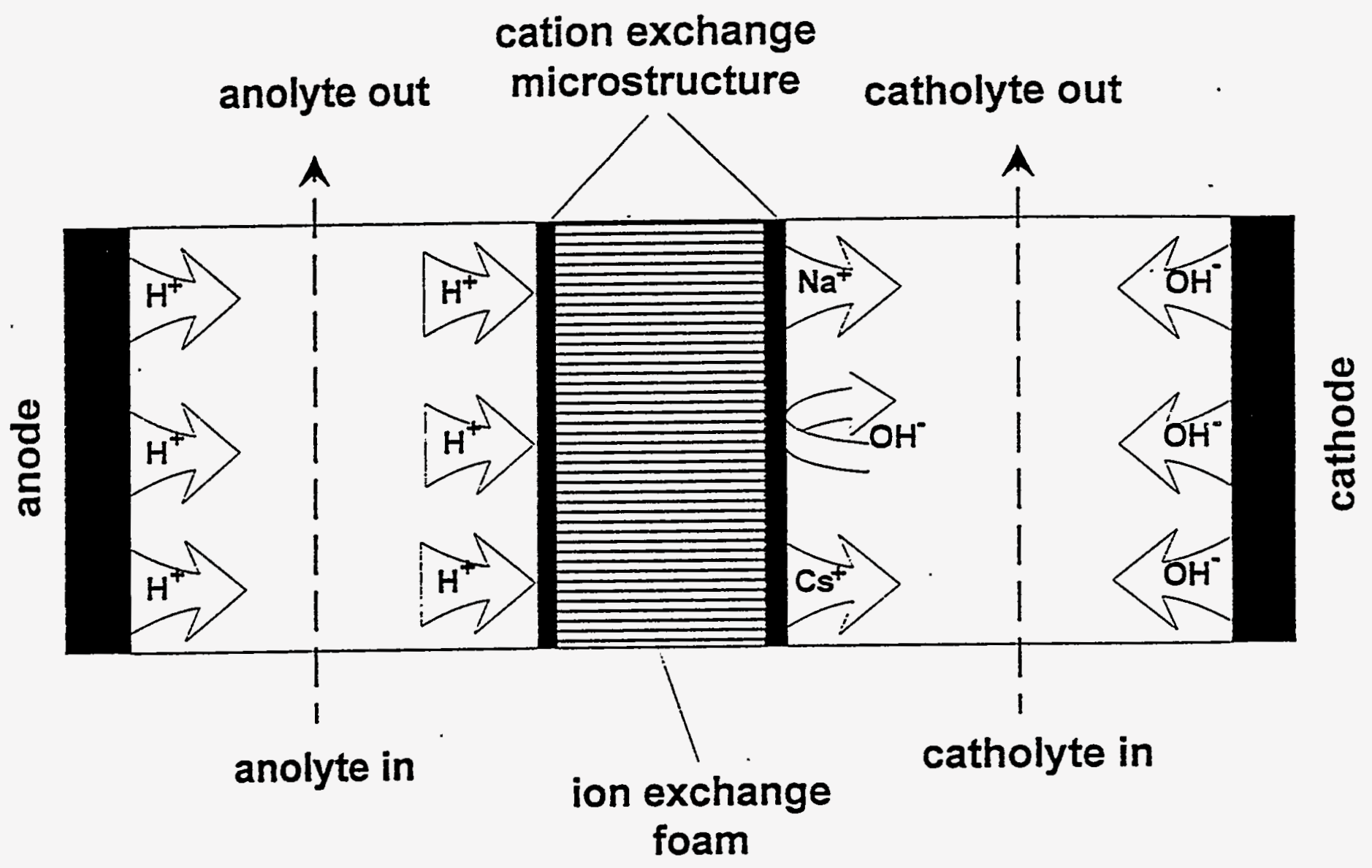

FIGURE 2.1. Schematic of a ETX Cell. 


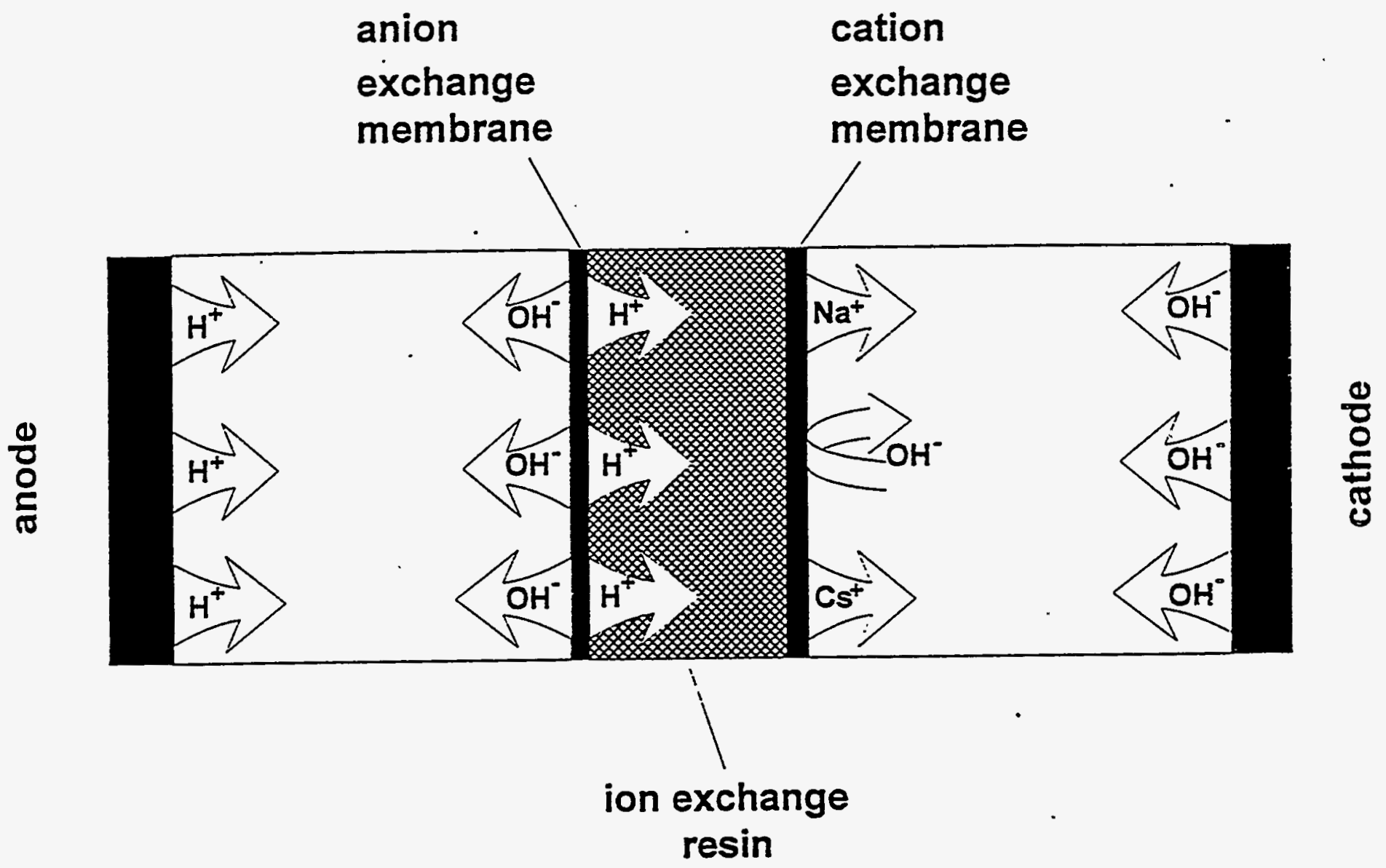

FIGURE 2.2. Schematic of a ED/LX Cell with Schematic of a ED/IX Cell With a Cation Exchange and an Anion Exchange Membrane Supporting the Resin. 


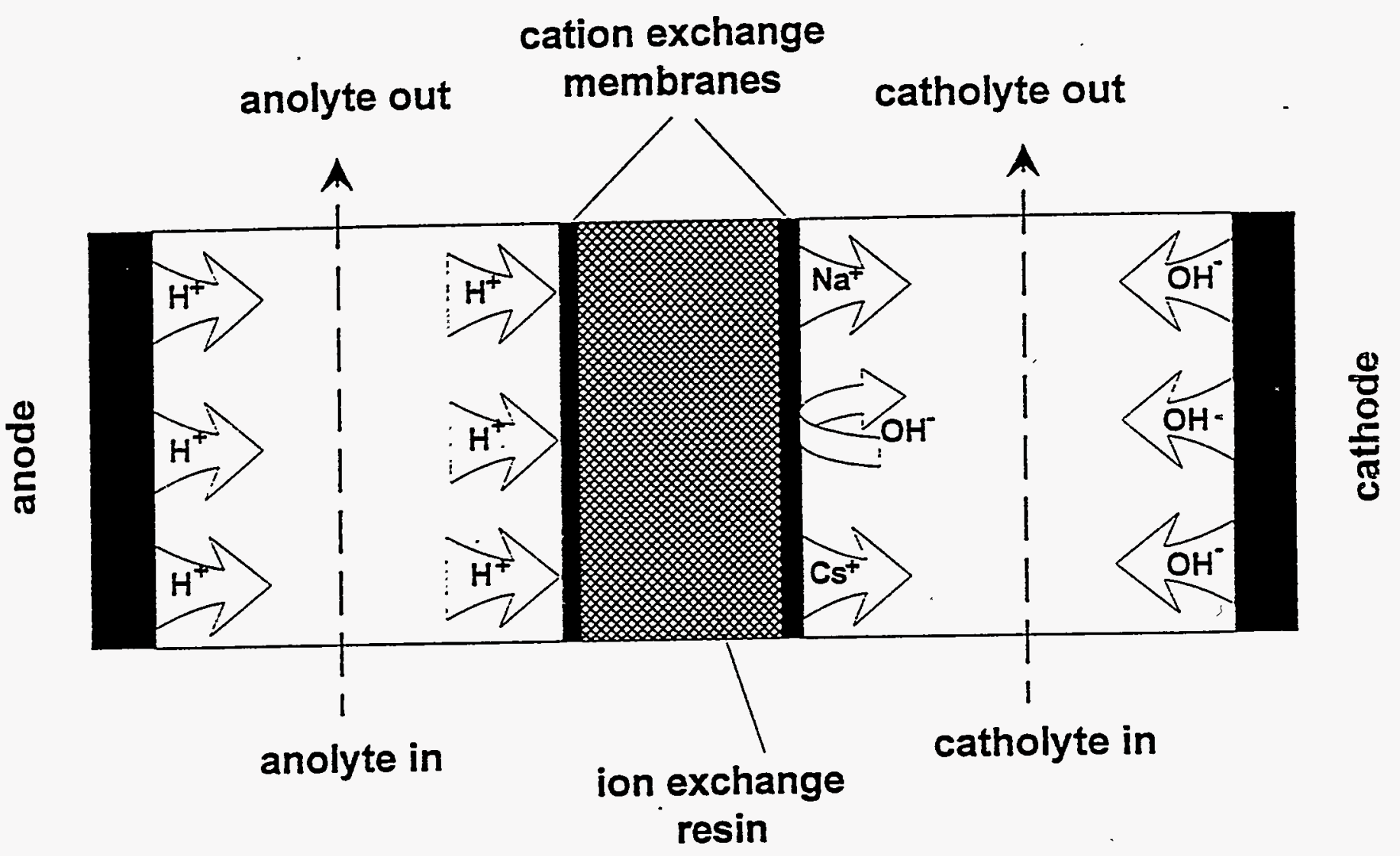

FIGURE 2.3. Schematic of a ED/IX Cell With Two Cation Exchange Membranes Supporting the Resin. 


\subsection{EXPERIMENTAL}

The various experimental procedures and equipment configurations used in the present study to evaluate the electrochemical elution processes are described below.

\subsection{ION EXCHANGER SELECTION}

The initial objective of electrochemical elution evaluation experiments were perform experiments at PNL using CS-100 ion exchange resin in the sandwiched bed configuration (ED/IX) and to perform experiments at AEA Technology using resorcinol formaldehyde (RF) and CS-100 ion exchange resins using the EIX and ED/IX configurations. The RF and CS-100 resins were chosen for this purpose because they were extensively tested at PNL and was found to be excellent for the removal of cesium from highly alkaline waste solutions. However, due to the shortage of availability of the CS-100 ion exchanger for the experiments at the subcontractors facility, Lewitat DN-KR (a phenol formaldehyde resin similar in composition to CS-100) was substituted for CS-100.

\subsection{CHEMICAL STABILITY TESTS}

Since Lewitat DN-KR resin was previously untested resin, chemical stability tests were performed to assess the stability of the resin when exposed to solutions of high sodium concentration (4M) and varying base concentration ( 0 to $1 \mathrm{M})$. The following is a detailed description of the experimental procedure used to determine the stability of the resin.

A 50ml sample of the resin was taken and rinsed in deionized water and air dried. The resin was split into $5 \mathrm{ml}$ samples and weighed to calculate the weight of the resin in each sample. The samples were taken in a glass column and $0.1 \mathrm{M}$ sulfuric acid was passed at a flowrate of $75 \mathrm{mls} / \mathrm{hr}$ for a period of $1 \mathrm{hr}$. Then the column was flushed with deionized water for $1 \mathrm{hr}$ at the same flowrate. Then $10 \mathrm{mM} \mathrm{NaNO}_{3}$ was passed through the column at a flowrate of $75 \mathrm{mls} / \mathrm{hr}$ and $15 \mathrm{mls}$ of the solution leaving the column was taken every 10 minutes until the columns were completely loaded. The resin was taken out of the column and $20 \mathrm{mls}$ of thermostated degradation solution (containing $4 \mathrm{M} \mathrm{NaNO}_{3}$ and 0 to $1 \mathrm{M} \mathrm{NaOH}$ ) was added to the resin set aside with periodic shaking for $1 \mathrm{hr}$. Changes in the color of the degradation solutions were noted. The resin was then rinsed 
rapidly with deionized water making sure that none of the resin is lost during the washing. The resin is placed back into the column and the above procedure is repeated (i.e., weighing the resin to determine if there was a loss of resin during degradation, passing 0.1M sulfuric acid solution to convert the resin into the acid form and obtaining loading curves with $10 \mathrm{mM} \mathrm{NaNO}$ solution). The loading curves obtained to pre-degradation are compared to those obtained after exposing to the resin to the degradation solution in order to determine the stability of the resin.

\subsection{BATCH EOUILIBRIUM EXPERIMENTS}

Batch equilibrium experiments were performed with Lewitat $D N-K R$ and RF resin. The experimental procedure used was șame as that developed by researchers at-PNL entitled "Determination of Batch Sorption Ratios for Ion Exchange Material Using Radionuclide Tracer Technigue" (Carlson et al., 1990).

\subsection{PREPARATION OF EIX FOAMS}

Preparation of the EIX foams involves preparation of the microporous structures of a strong acid ion exchanger and a microporous structure of the cesium selective ion exchanger (such as RF of Lewitat resins). The two structure preparation is described below.

\subsubsection{Preparation of the Microporous Structure}

The microporous structures were prepared from Purolite $\mathrm{Pr} \mathrm{CH}$, a strong acid cation exchanger with no preferential selectivity for cesium. The general procedure used for preparing the microporous structure is as follows. A $0.5 \mathrm{~kg}$ sample of damp cation exchanger was dried in a Gelson Creston Ltd. fluidized bed.drier at temperatures below the maximum recommended by the manufacturer. After over $95 \%$ of the water in the resin was removed, the resin was then ground in Gelson Creston Ltd. grinder to a mean particle size of $100 \mu \mathrm{m}$. The powdered resin was stored in a sealed container until required for preparation of the foam. A solution of Cariflex (a styrene butadiene copolymer) and genklene containing $18.75 \mathrm{wt} \%$ of the polymer was prepared by mixing the polymer and solvent and placed on a roller mixer for a period of not less than 24 hrs. The polymer solution was also stored in a sealed container until required for preparation of the foams. 
For the preparation of the foams, a known quantity of the resin was weighed and added to the same amount of the genklene solution. To this the binder solution prepared with the styrene butadiene solution prepared previously was added until the solution composition was 1:1:1 of resin : genklene : binder solution. The above solution was mixed with periodic addition of $0.5 \mathrm{~g}$ of genklene until a viscous solution that can be easily poured was obtained.This solution was poured onto a paper to give circular foam of 5 to $10 \mathrm{~cm}$ diameter and dried for a period of over $10 \mathrm{hrs}$ until solvent evaporates and a solid foam was obtained. The foam was carefully peeled of the paper and was placed in water for a period of about $4 \mathrm{hrs}$ to rehydrate and swell. The foam prepared this way is now ready for EIX testing.

\subsubsection{Preparation of the Macroporous Structure}

The macroporous structures were prepared using cesium selective ion exchange material ( $R F$ and Lewitat resins in the present study) using the following procedure. The ion exchange material was first washed with $10 \mathrm{BV}$ of $1 \mathrm{M} \mathrm{HNO}_{3}$ and then dried in a Gelson Crest Ltd. fluidized bed drier. The dried resin was then ground to a particle size of 50 to $100 \mu \mathrm{m}$ using a Glen Creston centrifugal mill. One part of the powdered resin was mixed with 1 part of binder solution and 6 parts of solvent and sprayed onto a polythene foam backbone. The resin coats the polythene structure to produce a three dimensional open structure with a capacity defined by the weight of the resin in the matrix. The foam was placed in deionized water to rehydrate the ion exchanger.

\subsection{EQUIPMENT DESCRIPTION}

In the following sections the equipment used for the evaluation of the electrochemical ion exchange process at AEA Technology and at PNL are described in detail. Since the equipment used at PNL and AEA Technology are essentially the same, the descriptions are combined as one.

A schematic diagram of the experimental design is shown in Figure 3.1. The apparatus consists of a three compartment plate and frame type cell. In the case of the EXX unit, the cell consists of an anode, a microporous cation exchange structure prepared from a strong acid ion exchange material such as Purolite $\mathrm{Pr} \mathrm{CH}$, the macroporous structure prepared from cesium selective ion exchange material such as RF or Lewitat, a second microporous structure of Purolite 
$\mathrm{Pr} \mathrm{CH}$, and the cathode. In the case of the ED/IX unit, the cell consists of an anode, a anion selective membrane, ion exchange resin to be evaluated, and a cation exchange membrane, and the cathode. In the EIX unit, proton transport from the anode compartment elutes the sodium and cesium from the resin whereas in the ED/IX unit protons generated by the electrochemical dissociation of water at the anion exchange membrane elutes the resin. In both the EIX and ED/IX units, it is possible that some $\mathrm{Na}^{+}$and $\mathrm{Cs}^{+}$ions may diffuse into the anode compartment primarily due to the difference in their concentrations across the membrane in the anode compartment. This is an undesirable stream and the concentrations of sodium and cesium in the anolyte stream are dependent upon the concentration gradients across the membrane. Since, the spent resin is primarily in the $\mathrm{Na}^{+}$form (although some cesium is present), it is possible that $\mathrm{Na}^{+}$ions will diffuse more than $\mathrm{Cs}^{+}$ion.

At AEA Technology, the anode and cathode are made from platinized titanium where as at PNL the cathode is made of platinized titanium and the anode is stainless steel. Polypropylene spacers or silicone rubber gaskets are included to prevent liquid seepage between the three compartments.

For the EIX experiments, the anolyte solution was 1000 mils of deionized water which was continuously recirculated through the anolyte compartment and the catholyte compartment was filled with deionized water and drained continuously as the solution in the compartment fills up. In the ED/IX mode, the anolyte solution was initially taken to be 1000 mils of deionized water which was continuously recirculated through the anode compartment. Due to the extremely low conductivity of the ED/IX cells, in the later experiments, the anolyte was changed to $1.0 \mathrm{M}$ nitric acid. It is important to mention here that the use of a high concentration of acid in the anolyte is primarily to improve the applied current and doesn't effect the objective of the program (i.e. to minimize the chemicals utilized) as the anolyte solution need not be changed due to the continuous electrochemical generation of the acid in the anode compartment. The catholyte in the ED/IX was taken to be 1000 mils of $0.05 \mathrm{M}$ nitric acid (the small amount of acid solution is initially required to maintain the conductivity at the start of the experiment). As the experiment proceeds, the conductivity of the catholyte increases with an increase in the basicity because of the electro-generated hydroxide ions and the sodium and cesium ions eluted from the resin. Tygon tubing or rubber tubing is used to 
connect between the pumps, the cathode and anode compartments and the holding tanks. A DC power supply is used to maintain constant current across the cell. An ammeter is included to monitor the current through the cell and a coulometer is used integrate the current to determine the charge passed during operation.

At AEA Technology, two solutions of feed were used during the loading cycle. The first containing inactive cesium while the other contains active ${ }^{137} \mathrm{Cs}$. A valve is included in the flow arrangement in order to allow periodic switching between the inactive and active feed solutions. The active cesium is used primarily to allow measurement of the extremely low cesium concentrations. The periodic introduction of active cesium in the feed helps minimize exposing the radiation worker to excessively high radiation dose.

At PNL all experiments were performed using inactive cesium. In order to enable analysis of the cesium concentration by AA and ICP, slightly a Na/Cs ratio of 5000 in the feed solution were used an compared to a $\mathrm{Na} / \mathrm{Cs}$ ration of 50,000 in NCAW simulant. 


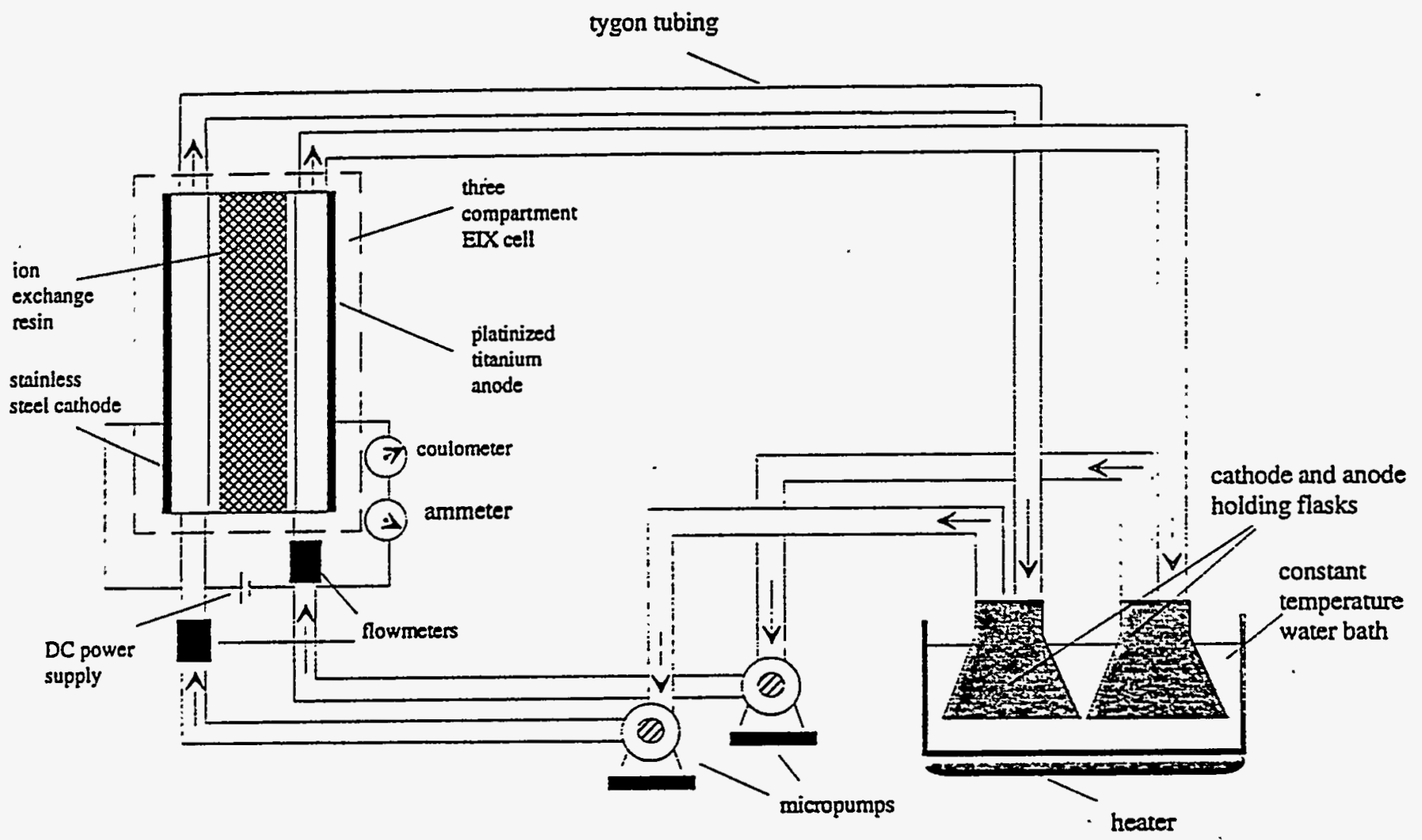

FIGURE 3.1. A Schematic of the Electrochemical Elution Test Cell Setup 


\subsection{EXPERIMENTAL PROCEDURE}

\subsubsection{Passive Loading}

Each experiment begins by loading the ion exchange resin passively by passing the feed solution through the column at a constant flowrate without the application of a potential across the cell. Once the column was loaded, it was flushed with deionized water in the case of simplified waste containing only $\mathrm{Na}$ and $\mathrm{Cs}$. In the case where the feed solution was NCAW, the column was flushed with $6 \mathrm{BV}$ of $\mathrm{NaOH}$ to remove any precipitated $\mathrm{Al}(\mathrm{OH})_{3}$ and then flushed with $6 \mathrm{BV}$ of deionized water.

\subsubsection{Electrochemical Elution}

Batch electrochemical elution experiments were conducted using loaded (spent) Lewitat, resorcinol formaldehyde and Cs-100 ion exchange resins. Initial experiments were focussed on determining the optimum process conditions (such as applied current, period of elution, and best of the EIX and ED/IX configurations) for maximum cesium recovery and current efficiency. When determining the optimum process conditions, simplified feed streams containing only $\mathrm{Na} / \mathrm{Cs}$ in a concentration ratio of 10,000 were used. Upon identification of the process conditions the influence of increasing the $\mathrm{Na}$ concentration in the feed on the cesium recovery efficiency was examined. Experiments were then performed with NCAW simulants in order to compare the elution characteristics with the acid elution characteristics already obtained at PNL.

To elute the resin, an electric potential was applied using a DC power supply to pass a constant current through the cell. Experiments were conducted to study the effect of applied current and the period of elution on the cesium recovery efficiencies. At the end of the experiment, the current is tumed off and the cesium concentration was measured in the catholyte and anolyte compartments. Then, 1.0 $\mathrm{M} \mathrm{HNO}_{3}$ was passed down the ion exchange resin to remove any cesium left on the ion exchange resin and permit a mass balance calculation. The effectiveness of the electrochemical process. is determined by computing the current efficiency which is defined as 


$$
\text { Regeneration Efficiency(\%) }=\frac{\text { moles of metal ionsin the catholyte }}{\text { moles of } \mathrm{H}^{+} \text {generated }}
$$

\subsubsection{Acid Elution}

After the column was electrochemically eluted, 1.M Nitric acid solution was passes down the column to desorb any remaining sodium and cesium from the column. From the moles of cesium in the acid wash solution, the total moles of cesium on the resin is computed as

$$
\text { Moles of Cesium on resin }=\text { Moles of cesium in [catholyte }+ \text { Acid wash] }
$$

A parameter of great importance in assessing the electrochemical ion exchange process is the cesium ion recovery in the catholyte, given by

$$
\text { Cesium Recovery }(\%)=\frac{\text { moles of cesiumin the catholyte }}{\text { moles of cesiumin the resin }}
$$

which is also defined as

$$
\text { Cesium Recovery }(\%)=\frac{\text { Total activity of cesiumin the catholyte }}{\text { Total activity of cesium on the resin prior to elution }}
$$

The resin regeneration efficiency and the cesium recovery efficiency were used to determine the overall effectiveness of the process over conventional acid elution.

\subsection{ANALYSIS AND CALCULATIONS}

\subsubsection{Analysis at PNL}

At PNL, sodium and cesium concentrations were measured by ICP MS techniques. All samples were diluted appropriately and the instrument was calibrated prior to every analysis using stock standard solutions. The sodium and cesium ion concentrations needed for the computation of the current efficiency and cesium recovery efficiency were computed from the ICP MS reading as 
[Metal Ion] in Catholyte $=\frac{[\text { Metal Ion] in ppm obtd. from ICP MS } \times \text { Sample Dilution Factor }}{\text { Mol.Wt. } \times 1000}$

\subsubsection{Analysis at AEA}

At AEA, the cesium concentrations in the catholyte, anolyte and resin wash solutions was measured by $\beta$ counting of the appropriate solutions using a LND Pancake $\alpha / \beta / \gamma$ detector (7311/8767) combined with a Harwell 6000 Series 6255 scaler timer unit. The detector was calibrated using various standard solutions containing a varying ${ }^{137} \mathrm{Cs}$ concentration which were prepared in a $1 \mathrm{M} \mathrm{NaNO}_{3}$ and $\mathrm{NaOH}(1$ to $4 \mathrm{M})$ environment. In all analysis, in order to reduce the effect of salt shielding on the $\beta$ particles, $0.1 \mathrm{ml}$ of the sample was taken in a lacquered aluminum planchet and $0.1 \mathrm{ml}$ of deionized water was added. The liquid was evaporated by placing the sample under IR lamp and then counted for $\beta$ radiation.

The sodium ion concentrations were determined at AEA using a Perkin Erlmer 2380 Atomic Absorption Spectrophotometer. A sodium hollow cathode lamp was used and the system wave length of the detector was set to $589 \mathrm{~nm}$ with a slit with of $0.7 \mathrm{~nm}$. Matrix modifiers of $0.1 \% \mathrm{HCl}$ and $0.1 \% \mathrm{KCl}$ were used as required. The AA was calibrated using standard solutions containing upto $1 \mathrm{ppm}$ of $\mathrm{Na}^{+}$. All experimental solutions were diluted in order to produce a sample containing $<1$ ppm of sodium.

The concentration of (active + inactive) cesium eluted in the catholyte solution was computed based on the assumption that the cesium concentration in solution is directly proportional to the activity of the feed solution as long as the activity doesn't change significantly during an experiment. Therefore,

$$
[C s] \text { in Catholyte }=[C s] \text { in Feed } x \frac{\text { Activity in Sample }}{\text { Activity in Feed }}
$$

The total sodium ion concentration in the catholyte solution is computed using the following relationship, 
$[\mathrm{Na}]$ in Catholyte $=\frac{[\mathrm{Na}] \text { in } \mathrm{ppm} \text { obtd. from AA } \times \text { Sample Dilution Factor }}{2300}$

In order to determine the cesium recovery efficiency using Equation 7, the activity of cesium on the column. The total activity of cesium on the column is determined using

Activityon column $=\sum$ Activities in feed spikes $-\sum$ Activities in effluent

\subsection{PREPARATION OF NCAW SIMULANT}

In Table 1, the various salts and their concentrations which make up the NCAW simulant are listed.

TABLE 1. Typical Constituents and Their Weights Taken for the Preparation of the NCAW Simulant.

\begin{tabular}{||c|c|c||}
\hline \multirow{2}{*}{ Component } & \multicolumn{2}{|c|}{ Amount Taken in 1 Liter } \\
\cline { 2 - 3 } & At PNL (grams) & At AEA (grams) \\
\hline $\mathrm{NaNO}_{3}$ & 26.3 & 22.0 \\
$\mathrm{Na}_{2} \mathrm{SO}_{4}$ & 21.4 & 21.3 \\
$\mathrm{KNO}_{3}$ & & 14.5 \\
$\mathrm{RbNO}_{3}$ & & \\
$\mathrm{Na}_{2} \mathrm{CO}_{3}$ & 24.6 & 24.7 \\
$\mathrm{NaNO}_{2}$ & 29.9 & 29.9 \\
$\mathrm{Na}_{2} \mathrm{HPO}_{4} 7 \mathrm{H}_{2} \mathrm{O}$ & & 6.7 \\
$\mathrm{Al}\left(\mathrm{NO}_{3}\right)_{3} 9 \mathrm{H}_{2} \mathrm{O}$ & & 155 \\
$\mathrm{NaF}$ & 3.7 & 3.75 \\
$\mathrm{NaOH}$ & 136.1 & 136 \\
$\mathrm{CsNO}$ & 0.18 & 0.0975 \\
\hline
\end{tabular}




\subsection{RESULTS AND DISCUSSION}

In this section, the results obtained during the electrochemical process evaluation at AEA Technology and PNL are presented. The results presented in this section include optimization of process parameter such as applied current density and period of elution, comparison between EIX and ED/IX modes of operation, effect of sodium concentration on cesium elution efficiency, effect of ion exchange membranes on the anolyte ionic concentration, results with NCAW simulant and cycling experimental results. The results of the batch equilibrium tests and the chemical stability data are included in the appendix.

\subsection{EFFECT OF BINDER ON EXCHANGER LOADING}

The ion exchange material in the EIX mode of operation is bound with polymers such a polystyrene and polybutadiene in order to form a foam. The foam helps improve the electrical conductivity of the ion exchanger. EIX foams were prepared using resorcinol formaldehyde and Lewitat DN-KR ion exchange materials. In Figures 4.1 and 4.2, the total cesium and sodium ion concentrations on the ion exchange foams prepared from Lewitat and resorcinol formaldehyde resins are shown. Also shown in the figures are the average cesium and sodium ion concentrations on the Lewitat and resorcinol formaldehyde resins in the absence of the foam. In all experiments the volume of the column was approximately $100 \mathrm{mils}$ and all columns were loaded using a simplified feed solution containing a $\mathrm{Na} / \mathrm{Cs}$ ratio of 10,000 and a feed flowrate of $5 \mathrm{BV} / \mathrm{hr}$. For the Lewitat and RF resins in the EIX mode of operation, the loading was carried out until $C / C_{0} \approx 1$ (where $C$ is the cesium concentration in the effluent and $C_{o}$ is the cesium concentration of the feed), whereas in the $\mathrm{ED} / \mathrm{IX}$ experiments especially with the $\mathrm{RF}$ resin, the loading was carried out until $\mathrm{C} / \mathrm{C}_{\mathrm{o}} \approx 0.2$. (It is essential to mention here that since elution rather than loading was the primary objective of the present study, column loading was carried out to ensure that there was sufficient cesium on the column rather than ensuring that the column is completely loaded). In these figures, the average values of sodium and cesium are shown because there was scatter of the ionic concentrations (over $50 \%$ ) in the resin possibly due to the reuse of the resin and foams over a majority of experiments due to a shortage of the ion exchange materials. The effect of the foam on the cation uptake by the 
resin was however very characteristic. For example, comparing the EIX and ED/IX performance in Figure 4.1, it can be seen that the cesium ion uptake was lowered by $20 \%$ in the Lewitat ion exchanger and by $60 \%$ in the resorcinol formaldehyde ion exchanger. Similarly, once again comparing the EIX and ED/IX performance in Figure 4.2, it can be seen that the sodium ion uptake by the Lewitat resin was reduced by $50 \%$ and that of the resorcinol formaldehyde by $75 \%$. One reason for the significantly lower cation uptake by the EIX foams as compared to using the ion exchanger as received (i.e., without the addition of any binders) is due to extremely small amounts of the ion exchanger in the foam due to the presence of the binder. Another reason for the low ion uptake could be due to a possible decrease in the effective surface area of the ion exchangers in the foam due to the presence of the binders. One additional point to note from the data in the Figures 4.1 and 4.2 is that with and without the foam the RF ion exchanger completely out performs the Lewitat ion exchanger, although, the differences in the performance is not so significant in the EIX mode of operation as compared to the ED/IX mode. 


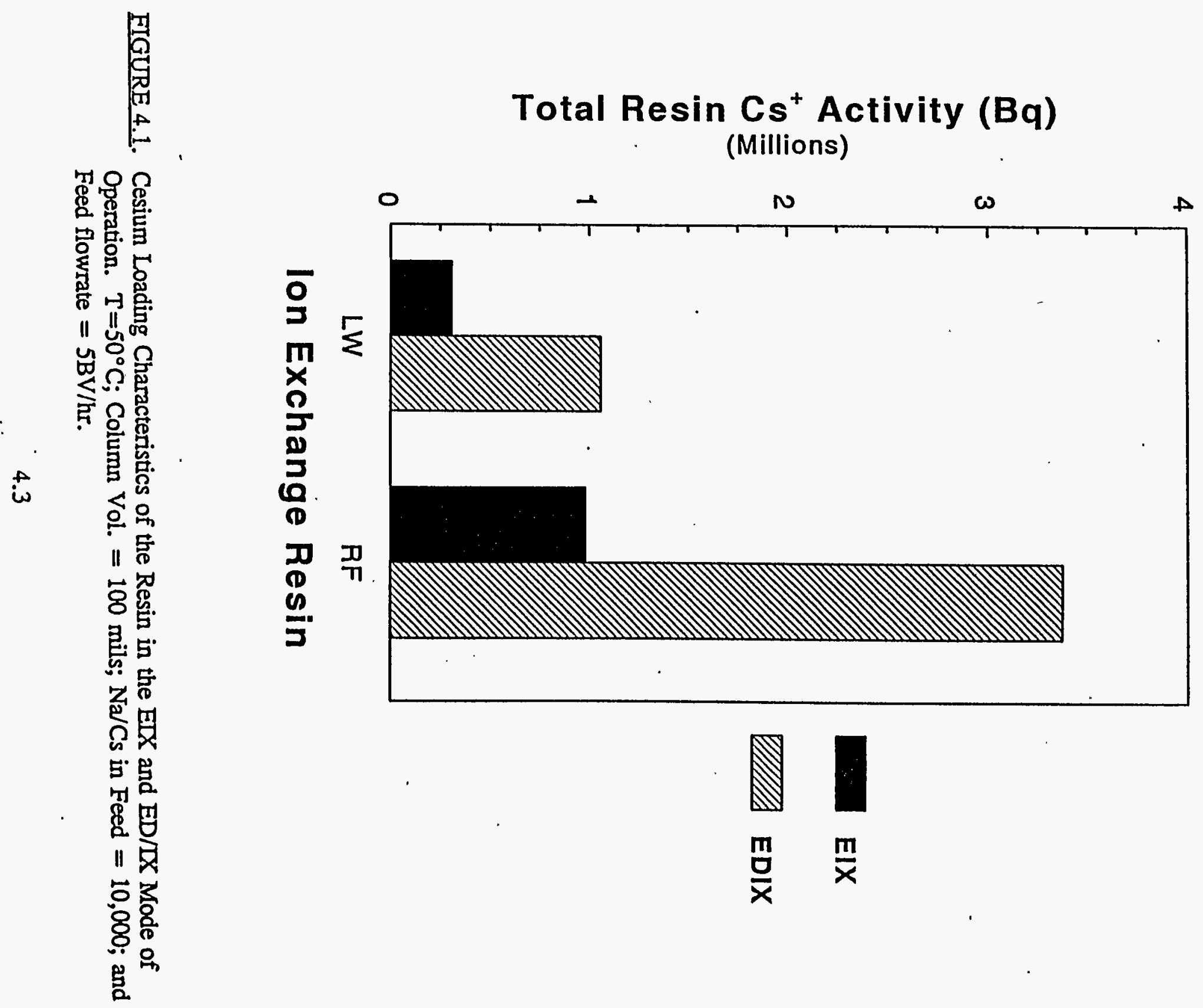




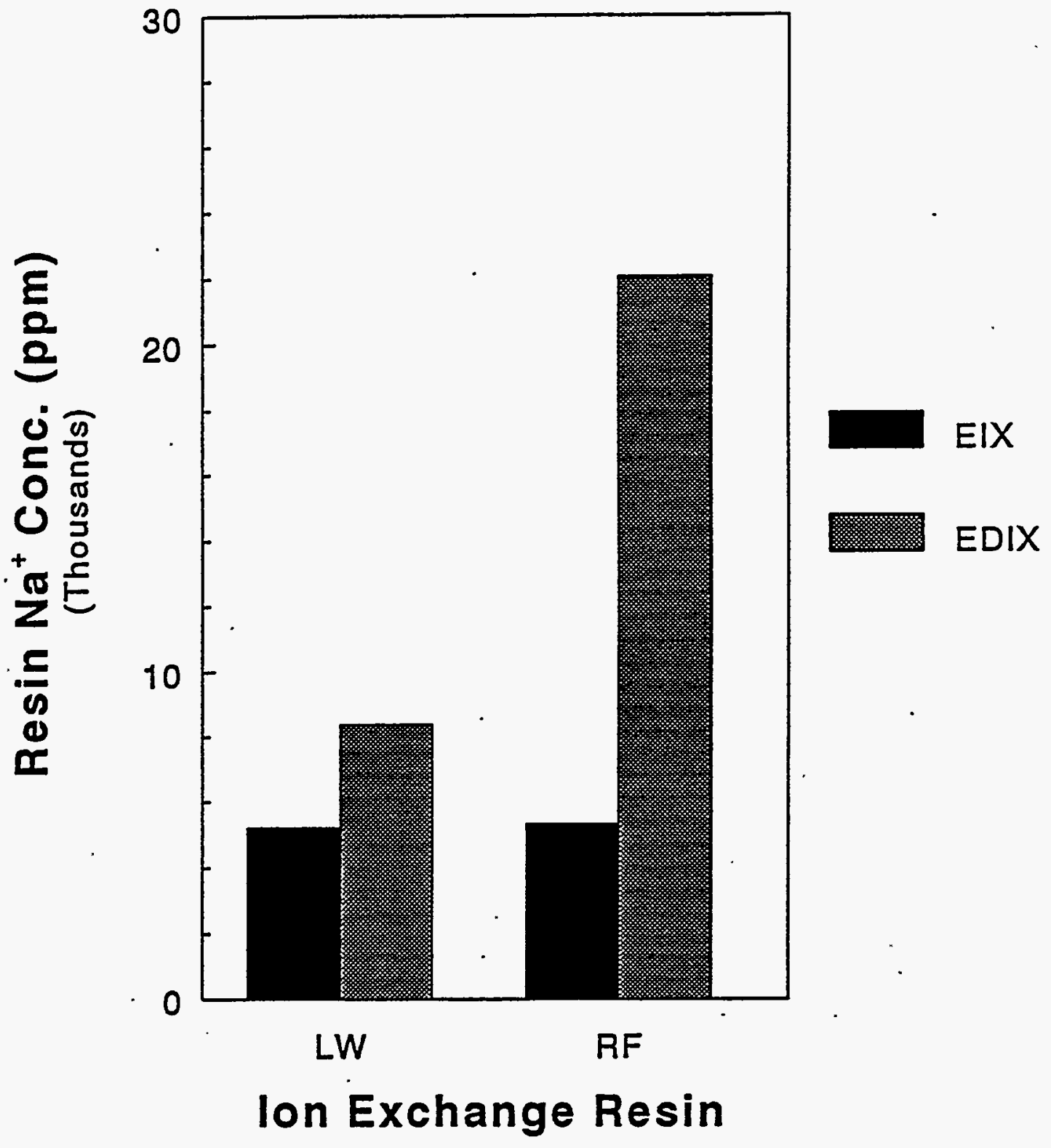

FIGURE 4.2. Sodium loading characteristics of the resin in the EIX and ED/IX mode of operation. $\mathrm{T}=50^{\circ} \mathrm{C}$; Column Vol. $=100$ mils; $\mathrm{Na} / \mathrm{Cs}$ in Feed $=10,000$; and Feed flowrate $=5 \mathrm{BV} / \mathrm{hr}$. 


\subsection{EFFECT OF APPLIED CURRENT AND ELUTION PERIOD}

Increasing the applied current density/elution period results in an increase in the rate/amount of proton generation. The protons (1) migrate into the resin and elute the sodium and cesium off the resin which then migrate into the cathode compartment or (2) just migrate through the resin and across the cation exchange membrane into the cathode compartment. If process 2 occurs, i.e, electro-generated protons migrate into the cathode compartment, then electrochemical elution is an ineffective process. The effectiveness of the electrochemical elution process depends upon the relative mobilities of sodium and cesium ions in the resin as compared to that of the protons. The effectiveness of the elution process is also dependent upon the relative affinity of the proton, over sodium and cesium ions, to the functional group of the ion exchanger.

In order to determine the effectiveness of the electrochemical process for the removal of cesium from the ion exchanger and to study the effect of current density and elution period upon the cesium recovery from the ion exchanger, experiments were conducted using the EIX foams of Lewitat and RF ion exchangers and simplified feed streams containing only sodium and cesium in a molar ratio of 10000:1. In Figure 4.3, the effect of changing the applied current density in the EIX mode of operation are shown. All experiments were run for a constant period of $12 \mathrm{hrs}$. The data from Figure 4 indicates that by increasing the applied current from $150 \mathrm{~mA}$ to $2 \mathrm{~A}$, the cesium recovered from the resin increases from $3 \%$ to $100 \%$, i.e, all of the cesium from the resin is eluted at higher applied current. This result is not surprising because an increase in the applied current results in an increase in the amount of $\mathrm{H}^{+}$ions generated, and thereby a increase in the amount of cesium eluted from the resin.

The same type of experiments were done in the ED/IX mode of operation. The effect of increasing the applied current density on the cesium recovery efficiency for the ED/IX mode of operation are shown in Figure 4.4. The results of the experiments in Figure 4.4, also show that the amount of cesium eluted from the resin increase with increasing current. However, the increase is much significant with the resorcinol formaldehyde resin as compared to the Lewitat resin. This difference is probably due to the much higher concentration of cesium on the resorcinol formaldehyde resin as opposed to the Lewitat resin (cf. Figure 4.1). For the resorcinol formaldehyde resin, the effect of increasing the elution period on the cesium recovery efficiency in 
both the EIX and ED/IX modes of operation at a constant applied current is shown in Figures 4.5 and 4.6. The results in Figures 4.5 and 4.6 indicate that as the elution period increases, the amount of cesium eluted from the bed increases. Once again, these results are not surprising, since as the elution period increases, the amount of cesium in the catholyte increases and the cesium recovery efficiency increases. 


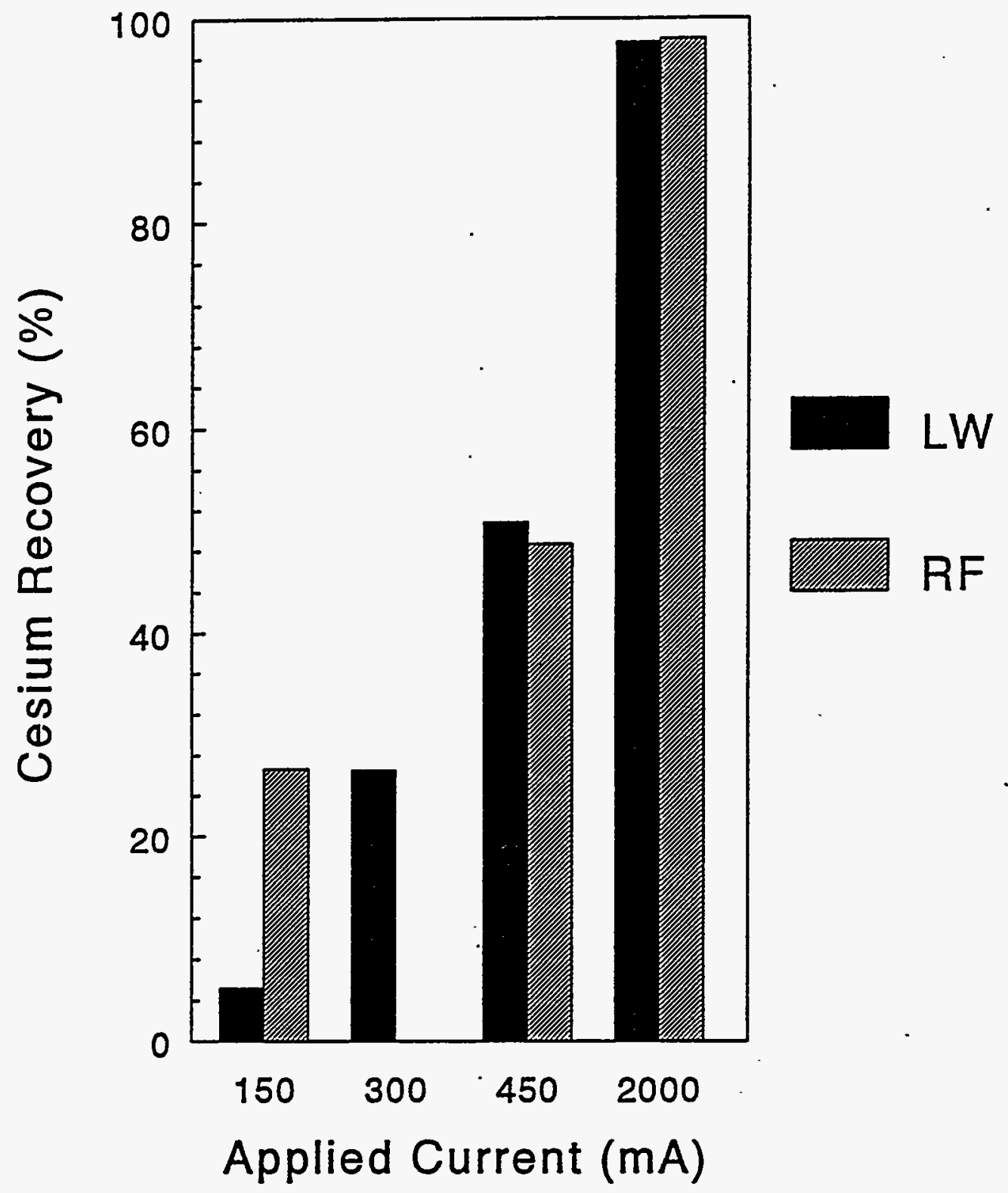

FIGURE 4.3. Effect of applied current on the cesium recovery efficiency during the EIX mode of operation. $\mathrm{T}=50^{\circ} \mathrm{C}$; Column Volume $=100$ mils, $\mathrm{Na} / \mathrm{Cs}$ in Feed $=10,000$; Feed Flowrate $=5 \mathrm{BV} / \mathrm{hr} ;$ Cathode and Anode Area $=50 \mathrm{~cm}^{2} ; \mathrm{LW}=$ Lewitat resin, and $\mathrm{RF}=$ Resorconol Formaldehyde resin. 


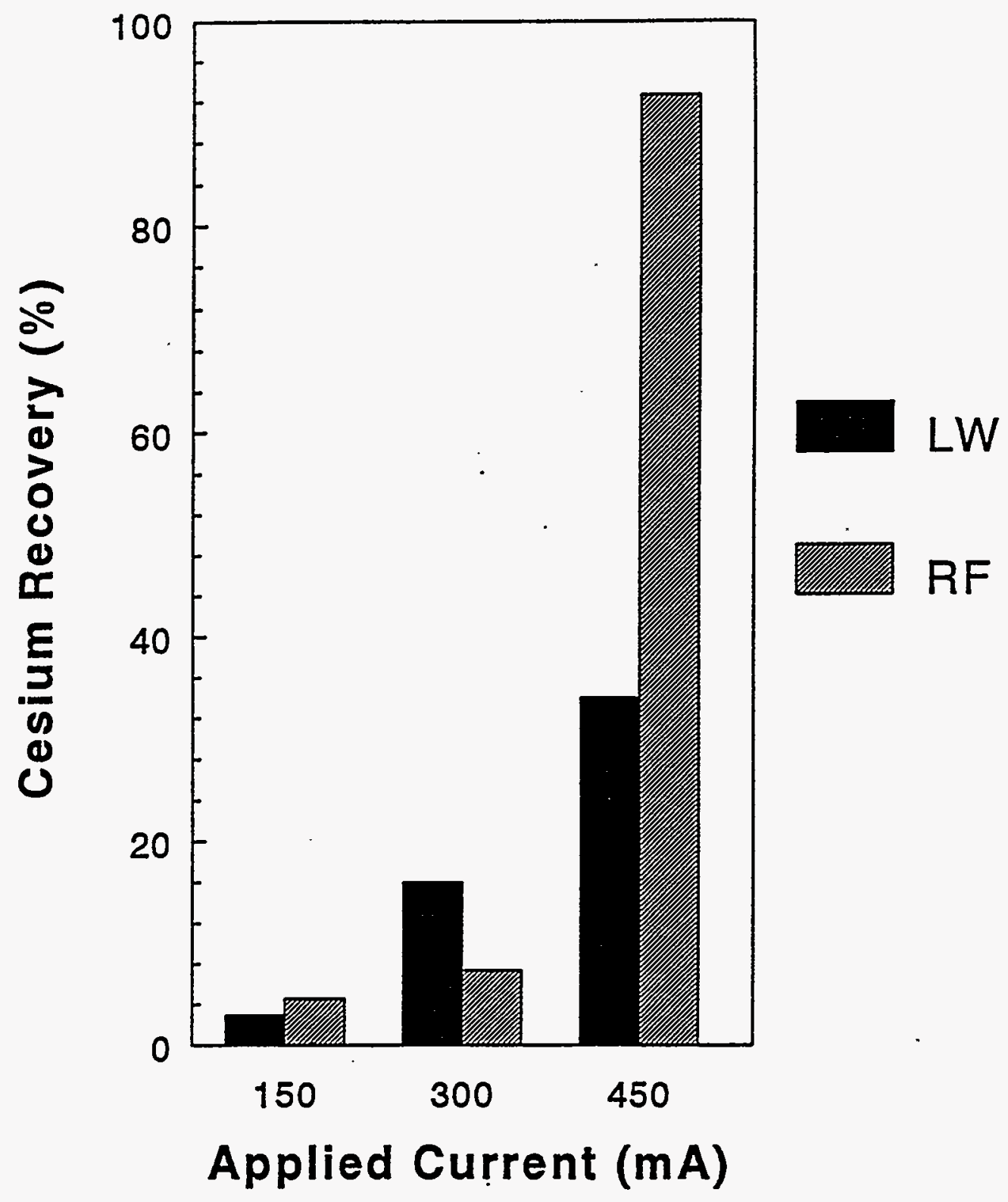

FIGURE 4.4.- Effect of applied current on cesium recovery efficiency during ED/TX mode of elution. $\mathrm{T}=50^{\circ} \mathrm{C}$; Column. Volume $=100 \mathrm{mils}, \mathrm{Na} / \mathrm{Cs}$ in Feed = 10,000; Feed Flowrate $=5 \mathrm{BV} / \mathrm{hr}$; Cathode and Anode Area $=50 \mathrm{~cm}^{2} ; \mathrm{LW}=$ Lewitat resin, and $R F=$ Resorconol Formaldehyde resin.. 


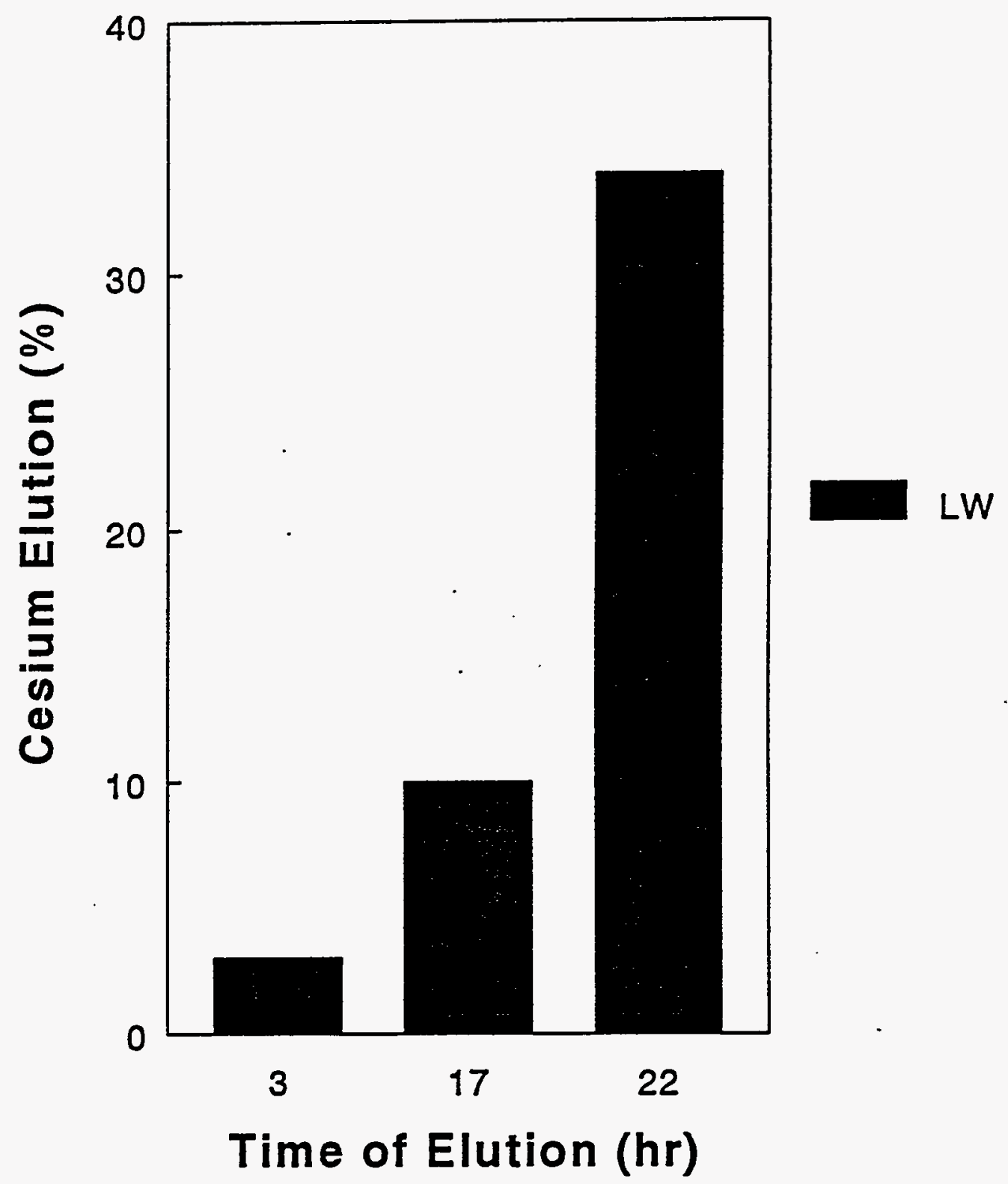

FIGURE 4.5. Effect of increasing the elution period on the cesium recovery efficiency during EXX mode of elution. $\mathrm{T}=50^{\circ} \mathrm{C}$; Column Volume $=100 \mathrm{mils}, \mathrm{Na} / \mathrm{Cs}$ in Feed $=$ 10,000; Feed Flowrate $=5 \mathrm{BV} / \mathrm{hr} ;$ Cathode and Anode Area $=40 \mathrm{~cm}^{2} ; \mathrm{LW}=$ Lewitat Resin. 
nll 


\subsection{COMPARISON BETWEEN EIX AND ED/IX}

In both the EIX and ED/IX modes of operation, the results of the present investigation indicate that maximum cesium recovery can be achieved at high currents and long elution periods. The primary difference between the EIX and the ED/IX mode of operation was found to be primarily in the electrical conductivity of the bonded resin in the EIX configuration and the unbounded resin in the ED/IX configuration. In the case of EIX since the resin particles are in intimate contact with each other, the electrical resistance is minimum and the potential drop required for the passage of sufficiently high currents is significantly smaller than the potential required in ED/IX where the particles are loosely packed. Also, the ED/IX mode of operation was found to be limited to low currents due to the rate limiting step of the water splitting reaction occurring at the anion exchange membrane. When the anion exchange membrane was changed to a cation exchange membrane, this limiting reaction step was eliminated and much higher current densities were achieved. However the potential drop required for the passage of the same amount of current was still significantly higher in the ED/IX mode than in the EIX mode of operation. The EIX mode, on the otherhand, was found to suffer from the disadvantage of having extremely low decontamination factors due to the relatively small amounts of the ion exchange resin and relatively slow rate of ion exchange because of the binders used to fabricate the foam.

\subsection{EFFECT OF EXTERNAL SODIUM CONCENTRATION}

In the preliminary investigation studies on the electrochemical elution process, all experiments were conducted at a sodium concentration of $1.0 \mathrm{M}$ and a cesium concentration of $0.1 \mathrm{mM}$. Experiments were also performed to study the effect of increasing the sodium concentration on the cesium elution efficiency. In Figure 4.7, the effect of changing the feed solution from $1 \mathrm{M}$ to $5 \mathrm{M} \mathrm{Na}$ to NCAW on the cesium elution efficiency is shown. All experiments were run at a maximum current of $2 \mathrm{~A}$ for a period of $12 \mathrm{hrs}$. It can be seen from Figure 4.7 that as the sodium concentration in the feed increases the cesium recovery efficiency decreases. The decrease in the cesium recovery efficiency with an increase in the external sodium ion concentration is primarily due to a decrease in the cesium concentration on the resin and the majority of the applied current is utilized for sodium ion transport. 


\subsection{COMPARISON WITH ACID ELUTION PROCESS}

The results presented in the above sections indicate that high applied current densities and longer elution periods are essential for the complete recovery of the cesium from the ion exchange resins. The results also indicate that EIX mode of operation suffers from the disadvantage of having extremely low amounts of ion exchange resin in the column as opposed to the ED/TX mode of operation. Based upon these results, experiments with NCAW waste simulant were conducted in the ED/IX mode of operation. Since the resorcinol formaldehyde resin performed better than the Lewitat resin, it was chosen for NCAW simulant testing. In the ED/IX mode of operation, the applied currents were significantly smaller than those achieved in the EIX mode primarily due to the limiting water splitting reaction at the anion exchange membrane. In order to improve the applied current in the ED/IX mode of operation, the anion exchange membrane was replaced by a cation exchange membrane. This resulted in a decrease in the potential drop across the cell and it was possible to pass currents as high as $2 \mathrm{~A}$. Using two cation exchange membranes and the RF resin in the ED/LX mode of operation, experiments were conducted with an NCAW simulant as the feed solution. In Figure 4.8, a typical loading (passive) curve for the RF resin and NCAW feed is shown and in Figure 4.9, the cesium recovery as a function of the elution period is shown. During the electrochemical elution, the volume of the catholyte was 1000 mils (10 BV). It can be seen from figure 4.9 , that $99.9 \%$ of the cesium is eluted from the resin within 2 hrs of operation. This result is extremely important since it indicates that the electrochemical 


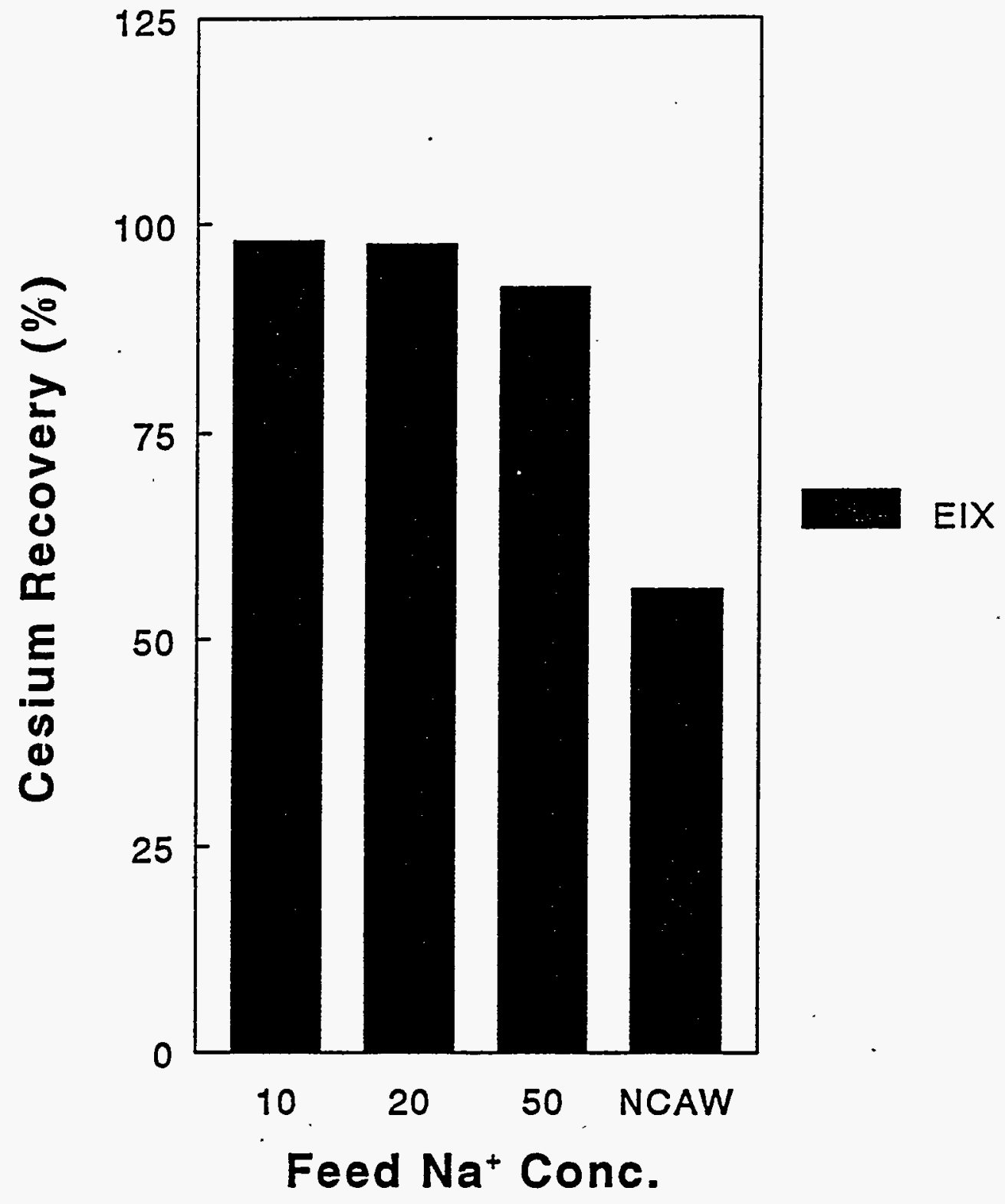

FIGURE 4.7. Effect of Sodium ion concentration of the cesium recovery efficiency. $\mathrm{T}=50^{\circ} \mathrm{C}$; Column Volume $=100$ mils, $\mathrm{Na} / \mathrm{Cs}$ in Feed $=10,000$; Feed Flowrate $=$ $5 \mathrm{BV} / \mathrm{hr}$; and Cathode and Anode Area $=40 \mathrm{~cm}^{2}$. 
elution process is comparable to the acid elution process which depending upon the concentration of the eluting acid typically requires between 1 to 5 hrs to completely elute the resin (Kurath et al., 1994). Comparing the total volume of waste generated during acid elution using $0.01 \mathrm{M}^{\mathrm{HNO}} 3$ with the volume of the catholyte which is equal to $10 \mathrm{BV}$, it can be seen that a waste volume reduction of $70 \%$ is achieved by the electrochemical process.

\subsection{EFFECT OF THE VOLUME OF THE CATHOLYTE}

In the electrochemical elution process, the catholyte solution containing the eluted cesium is separated from the ion exchange resin by cation exchange membranes. Back diffusion of the eluted cesium from the catholyte solution and onto the ion exchange resin depends upon the concentration gradient of cesium between the catholyte solution and the ion exchange resin. If this concentration gradient is greater than the electrical gradient (which opposes the reabsorption) across the membrane, then cesium ions will transfer back from the catholyte solution onto the resin. Since this concentration gradient is a direct function of the volume of the catholyte, a decrease in the volume of the catholyte should result in an increase in the catholyte cesium concentration, and hence an increase in the concentration gradient across the membrane. In order to investigate the influence of catholyte solution volume on the cesium elution, two identical experiments were conducted using CS-100 ion exchange resin and NCAW simulant (without $\mathrm{K}$ and $\mathrm{Rb}$ salts). In Figure 4.10, typical loading curves and in Figure 4.11, the electrochemical elution curves in the two experiments are shown. During elution, the volume of the catholyte in cell 1 was 1000 mils $(\approx 12 \mathrm{BV}$ as the Vol. of the cell used at PNL was $\approx 80$ mils) whereas in cell 2 , the catholyte volume was reduced to $1 / 4$ of its volume in cell 1 (i.e., 250 mils or $\approx 3 \mathrm{BV}$ ). It can be seen from Figure 4.10 , that cells 1 and 2 were loaded within experimental error to the same extent. Therefore, a direct comparision of the elution results would indicate if there is a reabsorption of the eluted cesium due to a decrease in the volume of the catholyte. Comparing the cesium elution profiles of cell 2 with those of cell 1 , it was found that the cesium concentration in cell 2 were a factor of $\approx 4$ times the concentration in cell 1 over the entire elution period. The results indicate that no reabsorption of cesium occurs and catholyte volumes as low as 3BV or less can be used to collect the eluted cesium. The above results 
are extremely significant since a reduction in the volume of the catholyte solution results in a decrease in the total volume of the waste generated during the electrochemical elution process. 


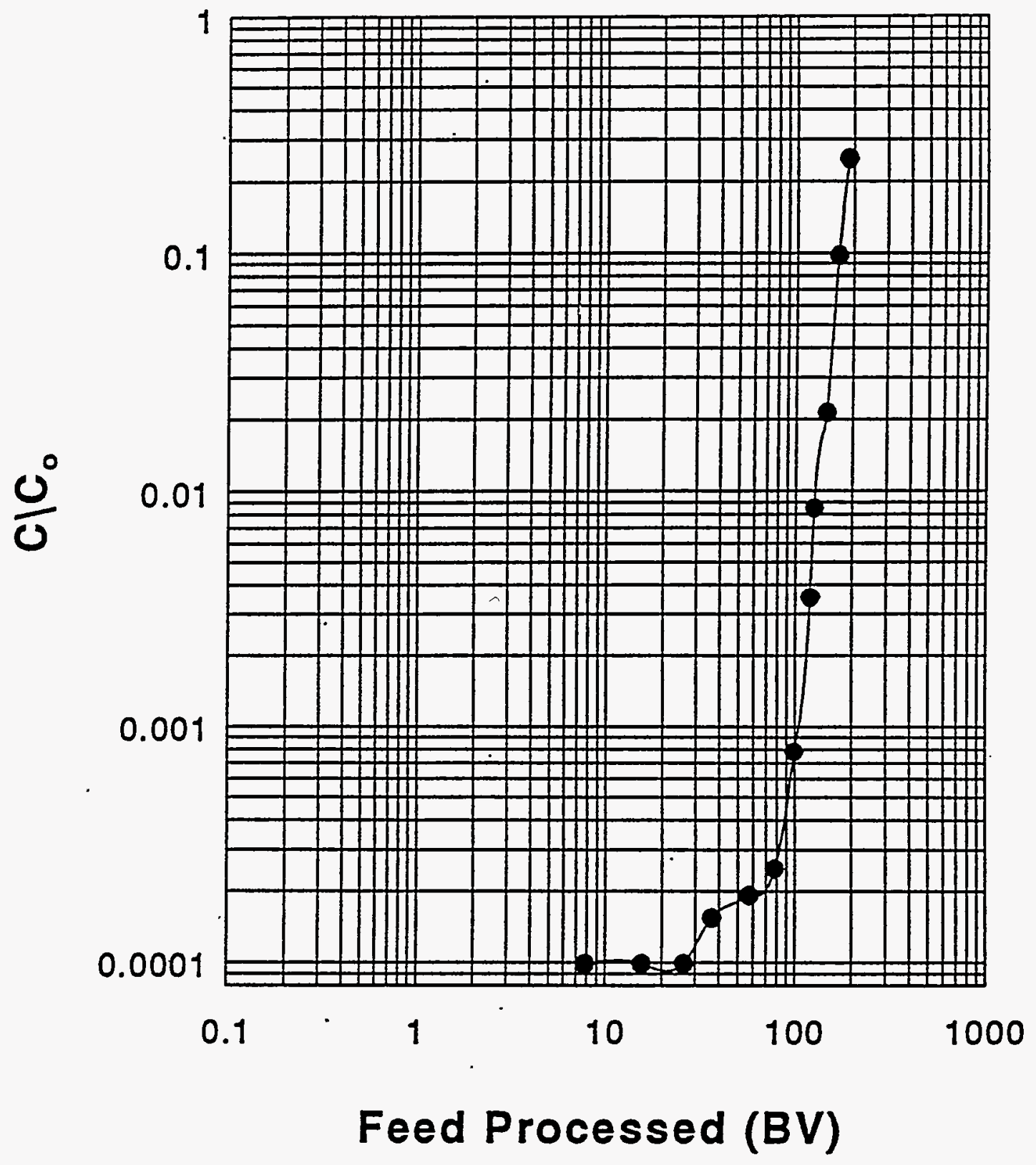

FIGURE 4.8. Typical Loading Curve for NCAW Simulant and Resorcinol Formaldehyde Resin. $\mathrm{T}=50^{\circ} \mathrm{C}$; Column Volume $=100 \mathrm{mils}$, and Feed Flowrate $=5 \mathrm{BV} / \mathrm{hr}$. 


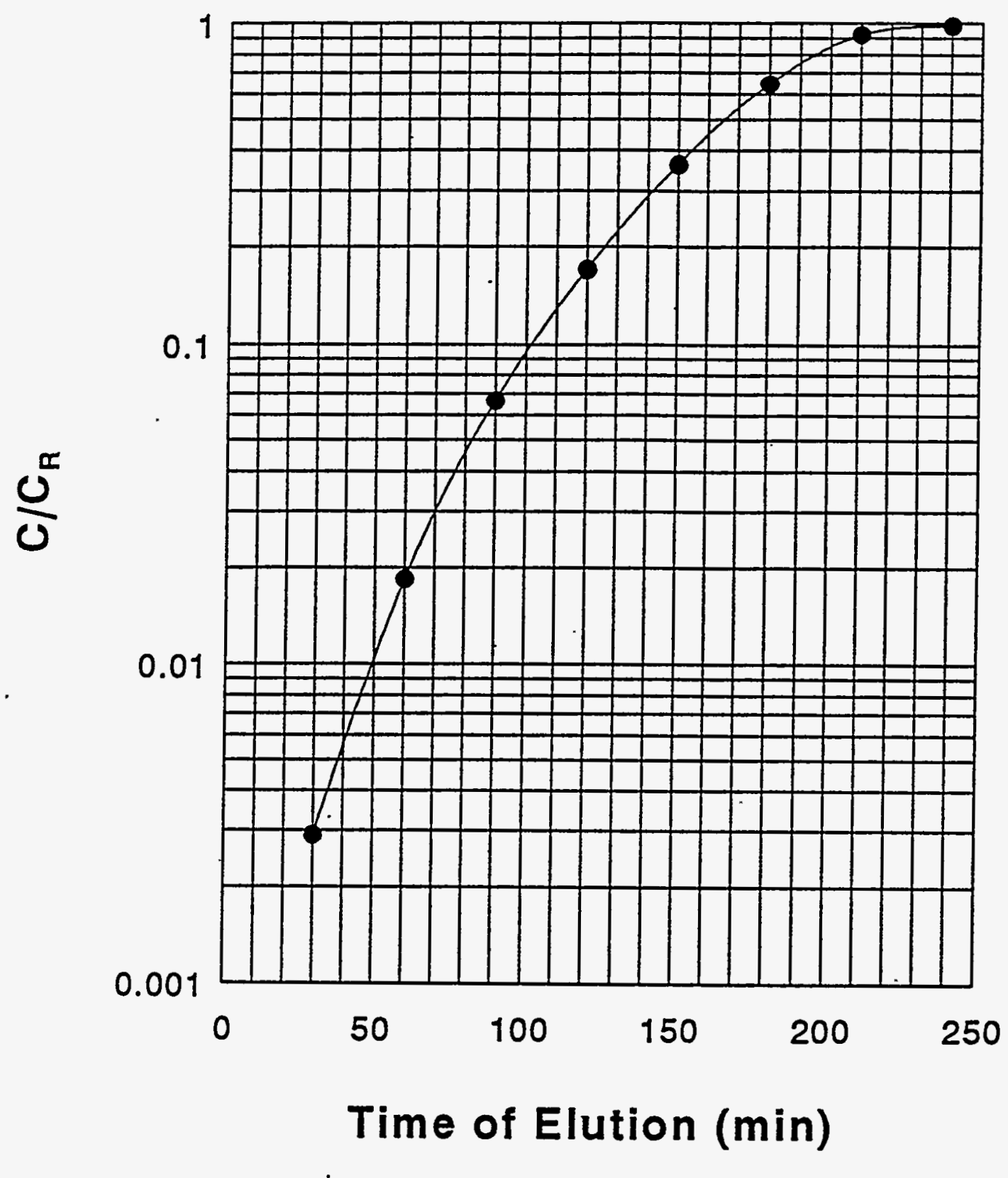

EIGURE 4.9. Typical Electrochemical Elution of Cesium as a Function of Time. $\mathrm{T}=50^{\circ} \mathrm{C}$; Column Volume $=100$ mils, Cathode and Anode Area $=50 \mathrm{~cm}^{2}$; Applied Current $=2000 \mathrm{~mA}$. 


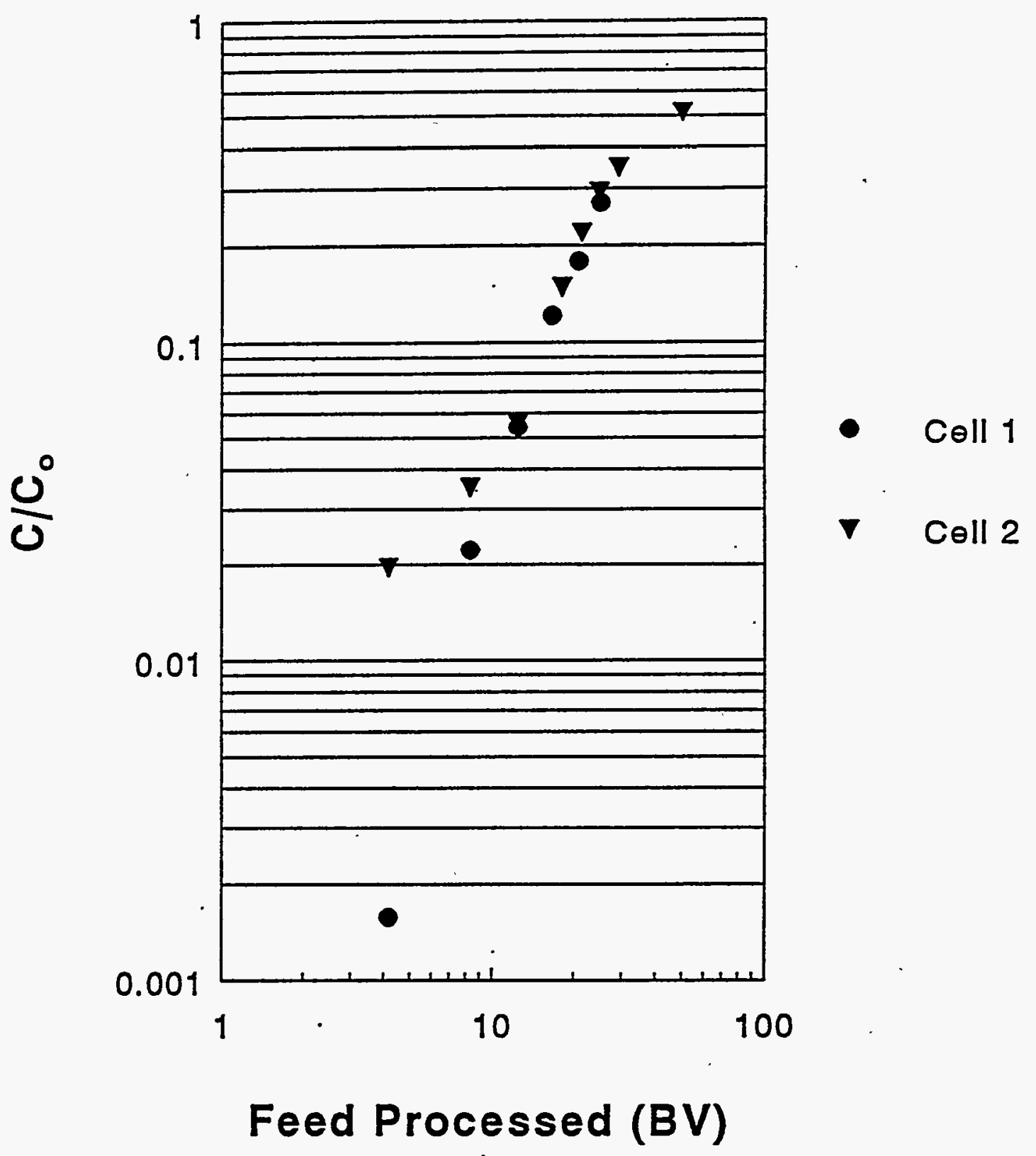

FIGURE 4.10. Cesium Loading Curves for CS-100 Ion Exchanger. NCAW Feed; $\mathrm{T}=25^{\circ} \mathrm{C}$; Column Volume $=80$ mils; and Feed Flowrate $=16 \mathrm{BV} / \mathrm{hr}$.

4.18 


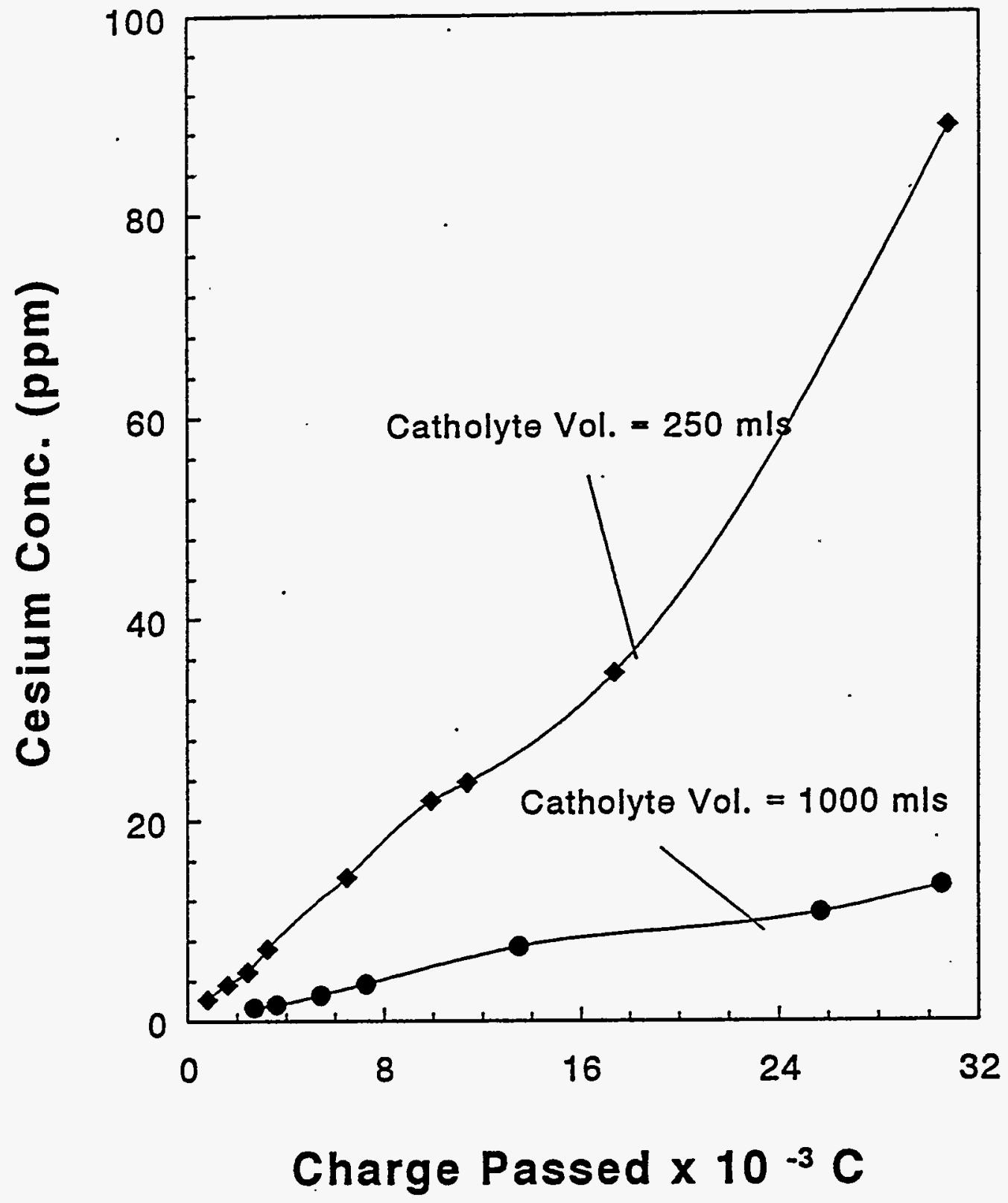

FIGURE 4.11. Cesium Elution From CS-100 Ion Exchanger as a Function of Time. Cathode and Anode Area $=40 \mathrm{~cm}^{2} ;$ and Applied Current $=900 \mathrm{~mA}$. 


\subsection{CONCEPTUAL FLOW DESIGN}

The present investigation indicates that the ED/LX mode of operation out performs the EDX mode of elution. Figure 5.1 shows a conceptual design in which the electrochemical cesium elution process is incorporated into a multi cell carousel arrangement. In such a process, the ion exchange resin supported by two cation exchange membranes is placed between the cathode and anode. Electrical switches (though not shown in the figure) will be included in such a manner that regeneration of any one of the columns can be started while the other cells are being loaded. $\mathrm{Na} / \mathrm{Cs}$ loading of the resin and resin washing occurs by passing the feed or wash solutions down (or up) the column as in conventional ion exchange process. When a particular column is loaded, the feed solution to the column is turned off and the electrical current through that cell is turned on. The cesium eluted from the resin is washed out by the catholyte stream and is concentrated and then vitrified. The cesium depleted feed is disposed as low level waste (LLW). The anolyte rinse solute is recycled back to the anolyte reservoir.

The most important challenge in the design of a pilot plant scale electrochemical cesium elution process would be in the preparation of large electrode surfaces with uniform current distribution. Such uniformity in current distribution is essential to ensure that the entire bed is regenerated. 


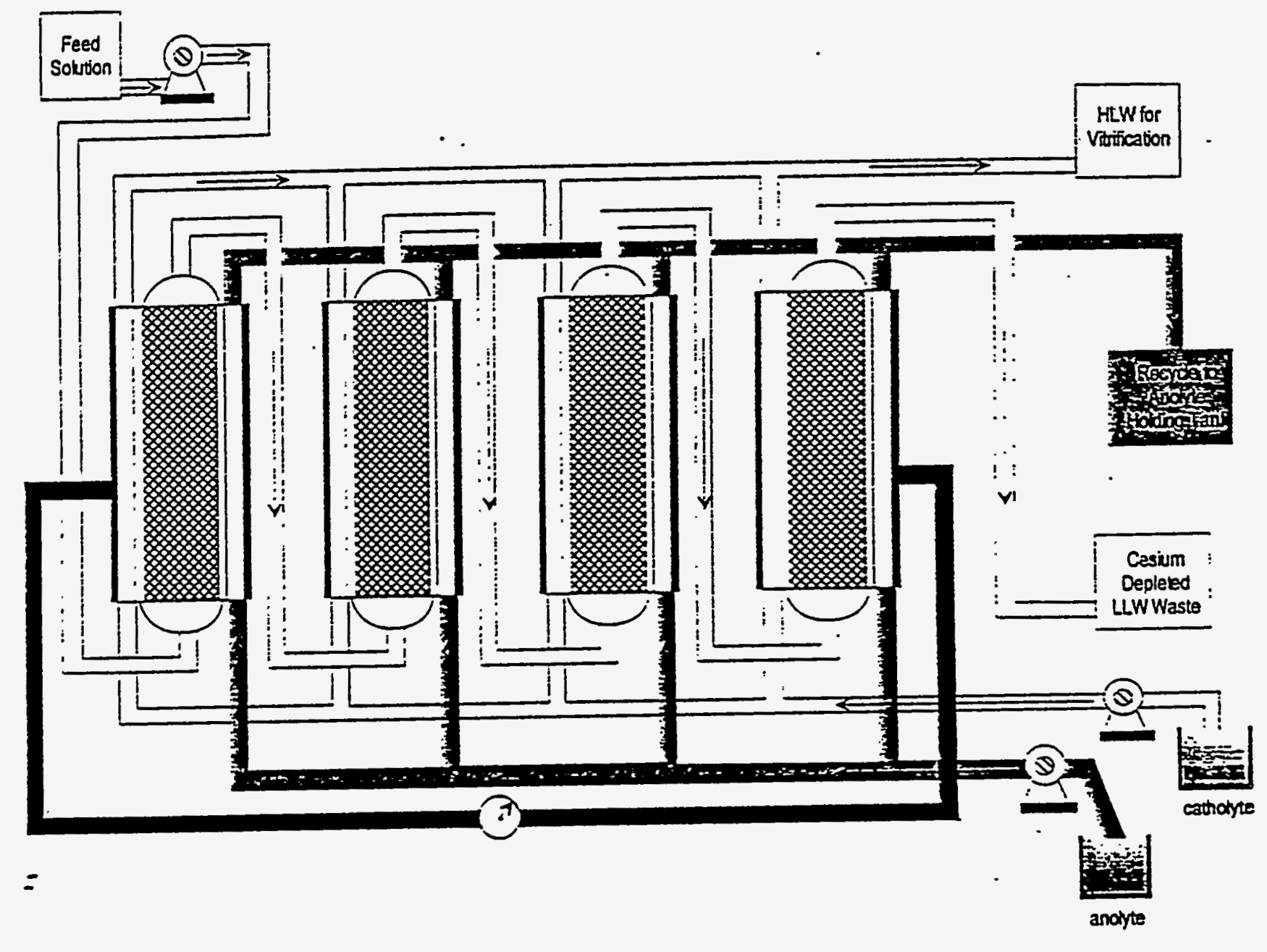

FIGURE 5,1. Conceptual Flow Diagram for the incorporation of the Electrochemical Elution into Conventional Multi-Column Configuration. 


\subsection{CONCLUSIONS}

The results of the preliminary investigation of the electrochemical elution process for the recovery of cesium from spent ion exchange resins are summarized below.

1. For a constant period (time) of elution, the cesium recovery increase from $3 \%$ to $100 \%$ when the applied current density was increased from 3 to $40 \mathrm{~mA} / \mathrm{cm}^{2}$.

2. For a fixed current, the cesium recovery increases with the time period of elution.

3. The ED/IX mode of operation appears to be preferred because the loading decontamination factors and ion exchange rate wasfound to be better in the absence of the binders added to create the foam in the EIX mode of operation.

4. Based on the batch distribution coefficient (Kd) values, the resorcinol formaldehyde resin outperformed the Lewitat resin.

5. The limiting current with the EIX configuration was much higher than that of the ED/IX configuration due to the differences in the electrical conductivities of resin bonded with additives into a foam as compared to the resin being used as received. The bonded resin in the EIX mode of operation, however, was found to suffer from a reduced capacity and slow rate of ion exchange due to the presence of the additives.

6. Improvements in the limiting currents were obtained for the $E D / D X$ mode by using two cation exchange membranes to support the ion exchange resin as opposed to a cation exchange and an anion exchange membrane as in conventional ED/IX mode. However, the potential drop required for the passage of the same amount of current in the ED/LX mode was still much higher than that required in the EIX mode (at $2 \mathrm{~A}$, the voltage drop across the cell was $40 \mathrm{~V}$ as opposed to $12 \mathrm{~V}$ ).

7. Since cesium and sodium eluted in the catholyte exist as the hydroxides, this eliminates the acid neutralization step needed in the conventional elution process in order to prepare a $\mathrm{pH}$ 12 waste solution suitable for the tank farm specifications.

8. An increase in the sodium concentration from $1 \mathrm{M}$ to $5 \mathrm{M}$ results in a decrease of the cesium recovery efficiency for the same elution period and elution current density. This is due to an increase of the sodium concentration on the resin and majority of the current utilized in eluting the sodium in the bed.

9. The ED/LX mode of operation with two cation exchange membranes supporting the ion exchange resin, appears to be the obvious choice for future studies. 
10. Experimental evaluation with NCAW waste with RF resin in the ED/IX mode indicates that $99 \%$ of the cesium is eluted from the resin after just three hours of operation.

11. Comparison of the eluate volumes with conventional acid elution and electrochemical elution processes using NCAW simulant and RF resin, the results of the present testing indicate that a volume reduction of $70 \%$ or more (10 BV in ED/IX as compared to $30 \mathrm{BV}$ in conventional

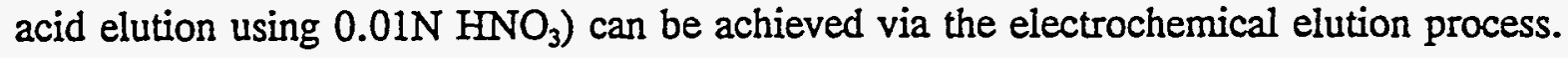

12. A further $75 \%$ decrease in the volume of the catholyte solution (which contains the eluted cesium) indicates that there is no significant differences in the elution characteristics. These results indicate that there is no reabsorption of the eluted cesium by the resin from the catholyte solution, which suggests that eluting solution volumes as low as $2.5 \mathrm{BV}$ are sufficient to recover the cesium from the ion exchange material. 


\subsection{REFERENCES}

Adams, R. J. W. and Hudson, M. J., "Reversible Extraction of Ionic Species Using Electrochemically Assisted Ion Exchange", Solvent Extraction and Ion Exchange, 9(3), 497, 1991.

Bridger, N. J., Jones, C. P., and Neville, M. D., "Electrochemical Ion Exchange", J. Chem. Tech. Biotech., 50, 469, 1991.

Kurath, D.E., Bray, L. A., Brooks, K. P., Brown, G. N., Bryan, S. A., Carlson, C. D., Carson, K. J., DesChane, J. R., Elovich, R., J., and Kim, A. Y., Experimental Data and Analysis to Support the Design of an Ion Exchange Process for the Treatment of Hanford Tank Waste Supernatant Liquids", Report submitted to DOE, January, 1994.

Nott, B. R. " Electrodialytic Decontamination of Spent Ion Exchange Resins from CANDU Primary Heat Transport Circuits", Water Chemistry and Corrosion Problems in Nuclear Power Plants, International Atomic Agency, IAEA-SM-264/32, 295, 1983.

Parise, P. L. and Paresh, B. S., "The Use of Ion Pure Continuous Deionization for the Production of Pharmaceutical and Semiconductor Grades of Water", UltraPure Water Expo, 1990.

Wilkins, F. C. and McConelee, P. A., "Continuous deionization in the Preparation of Microelectronic Grade Water", Solid State Technology, 1988. 
APPENDIX A

CHEMICAL STABILITY TESTS OF LEWITAT REISN 


\section{CHEMICAL STABILITY TESTS OF LEWITAT RESIN}

The method used to determine the chemical stability of the Lewitat DN-KR resin is described in Section 3.2. The four degradation solutions used in the testing are:

1. $4 \mathrm{M} \mathrm{NaNO}$

2. $4 \mathrm{M} \mathrm{NaNO}_{3}$ and $10 \mathrm{mM} \mathrm{NaOH}$

3. $4 \mathrm{M} \mathrm{NaNO}$ and $100 \mathrm{mM} \mathrm{NaOH}$

4. $4 \mathrm{M} \mathrm{NaNO}$ and $1 \mathrm{M} \mathrm{NaOH}$

When the resin was exposed to solutions containing small amounts of base $(>10 \mathrm{mM})$, the eluant was observed to be straw colored with the intensity of the coloration decreasing as the experiment progressed. Also, it was noted that the intensity of the coloration increases with increasing alkalinity. No analysis were performed on the eluant to determine the source of the coloration, although it is speculated that the coloration was due to the solubilization of the resin in highly alkaline solutions. A more exact determination of the effect of the degradation solution can be obtained by examining the elution characteristics of the resin pre and post degradation. In Figures A1 to A4, the sodium loading curves of the resin obtained before and after exposing the ion exchanger to the degradation solution are shown. The results of the data in Figures A1 to A4, indicate that the elution characteristics are not effected by treatment with solutions containing $4 \mathrm{M}$ $\mathrm{NaNO}_{3}$ and upto $100 \mathrm{mM} \mathrm{NaOH}$. However, when the resin is contacted with $4 \mathrm{M} \mathrm{NaNO}_{3}$ and $1 \mathrm{M}$ $\mathrm{NaOH}$, it can be seen from Figure A4, that the elution characteristics are significantly effected by the presence of the high concentration of the base. The conciusions of the stability tests are that the Lewitat resin is stable in moderately alkaline solutions but its performance is significantly reduced in highly alkaline solutions. Also, the presence of $\mathrm{NaNO}_{3}$ on its own doesnot influence the resin performance. 


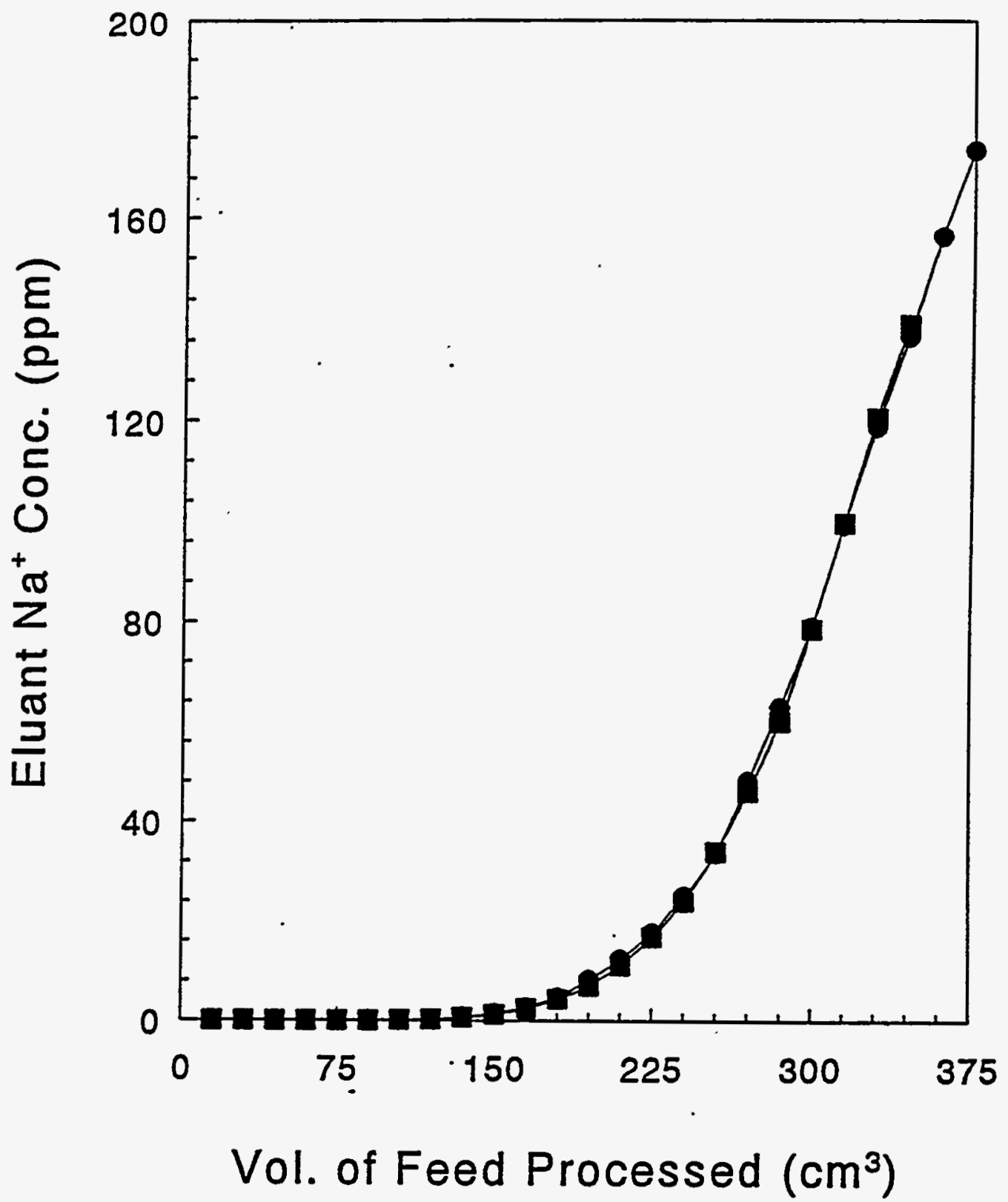

FIGURE A1. Sodium Elution Curves for Lewitat DN-KR Ion Exchange Resin. -: Pre-degradation; $\mathbf{E}$ : Post degradation Using $4 \mathrm{M} \mathrm{NaNO}_{3}$.

A.2 


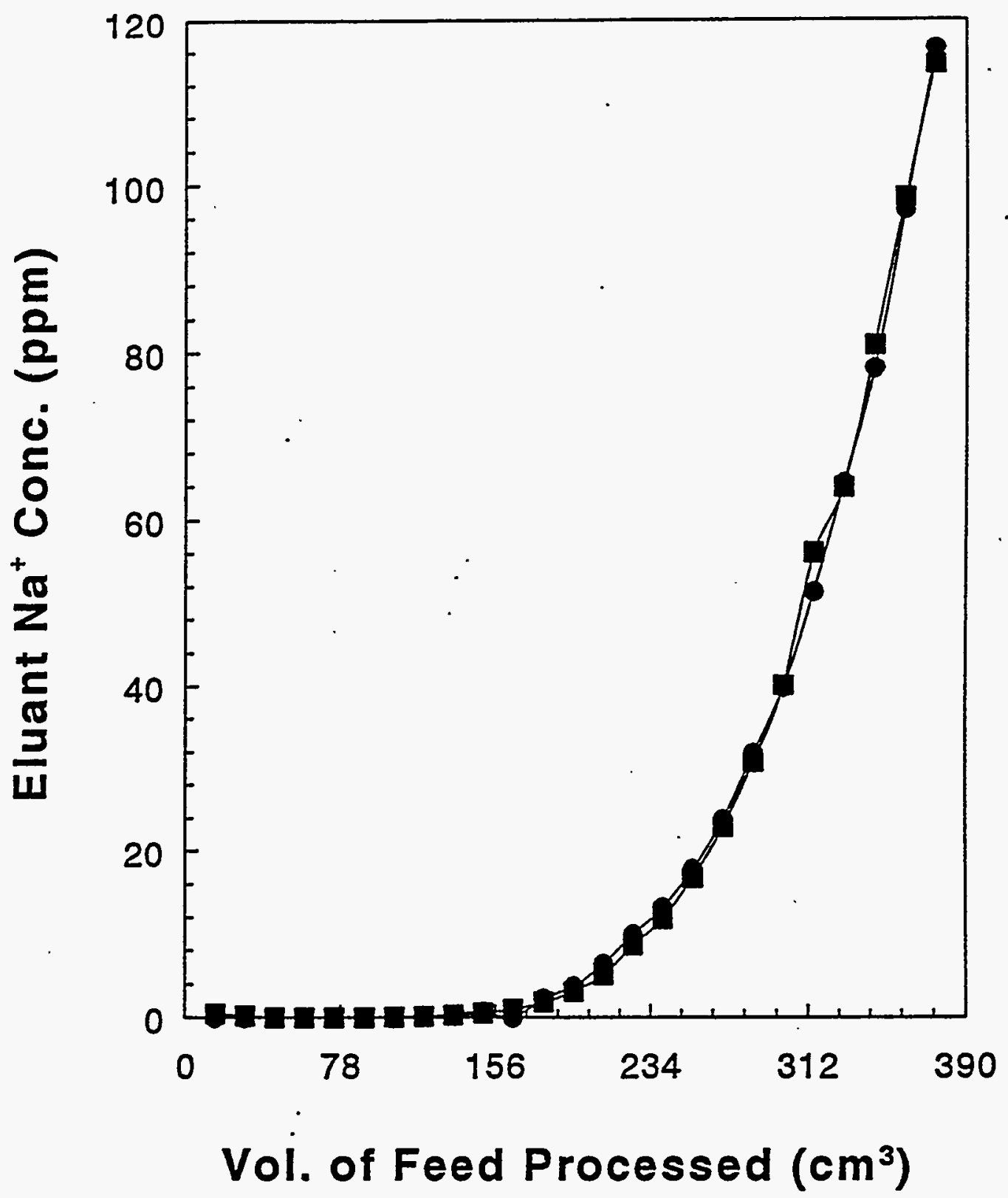

FIGURE A2. Sodium Elution Curves for Lewitat DN-KR Ion Exchange Resin. -: Pre-degradation; $\mathbf{E}$ : Post egradation Using $4 \mathrm{M} \mathrm{NaNO}_{3}$ and $10 \mathrm{mM}$ $\mathrm{NaOH}$.

A.3. 


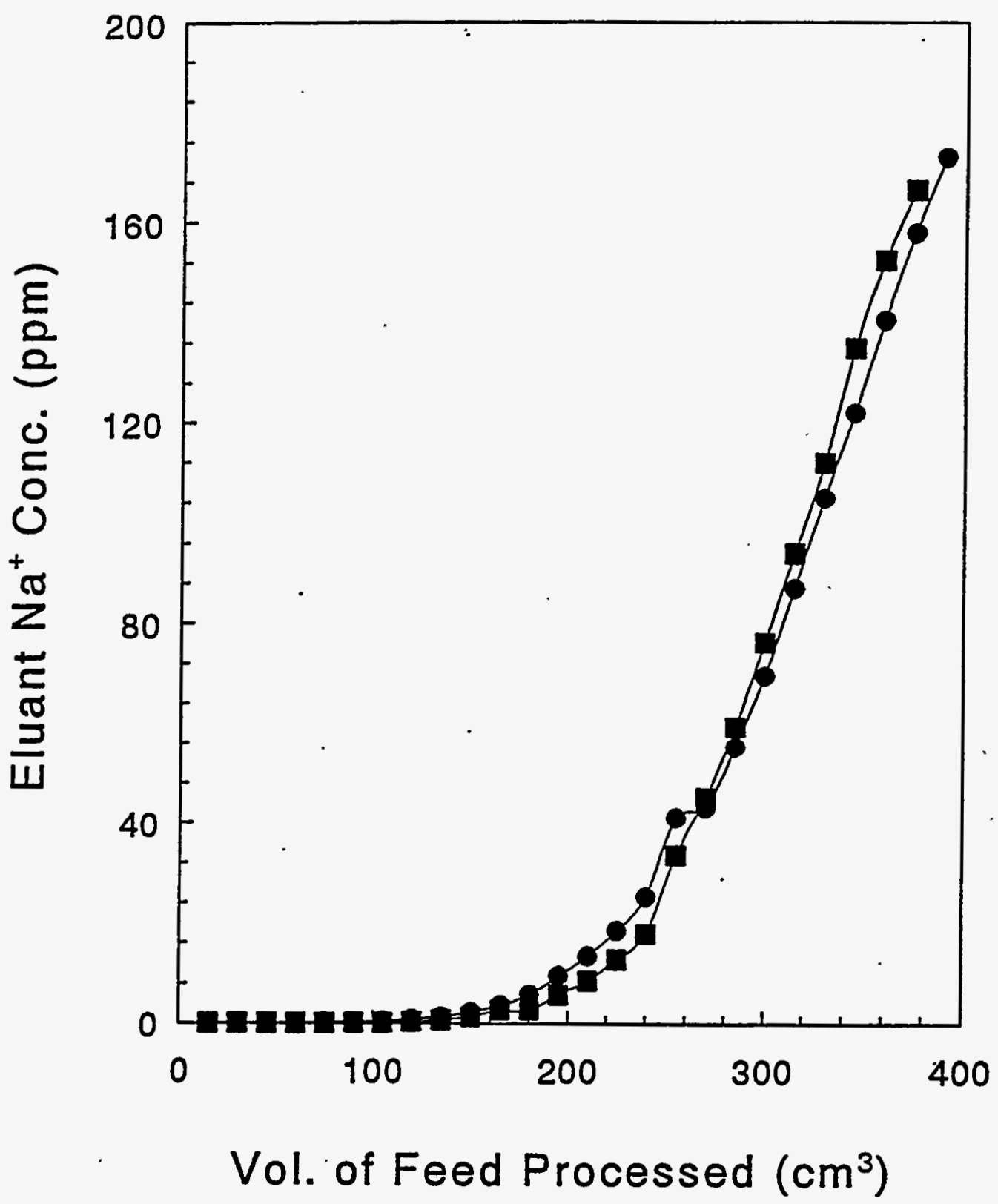

FIGURE A3. Sodium Elution Curves for Lewitat DN-KR Ion Exchange Resin. -: Pre -degradation; $\mathbf{n}$ : Post Degradation Using $4 \mathrm{M} \mathrm{NaNO}_{3}$ and $100 \mathrm{mM}$ NaOH. 


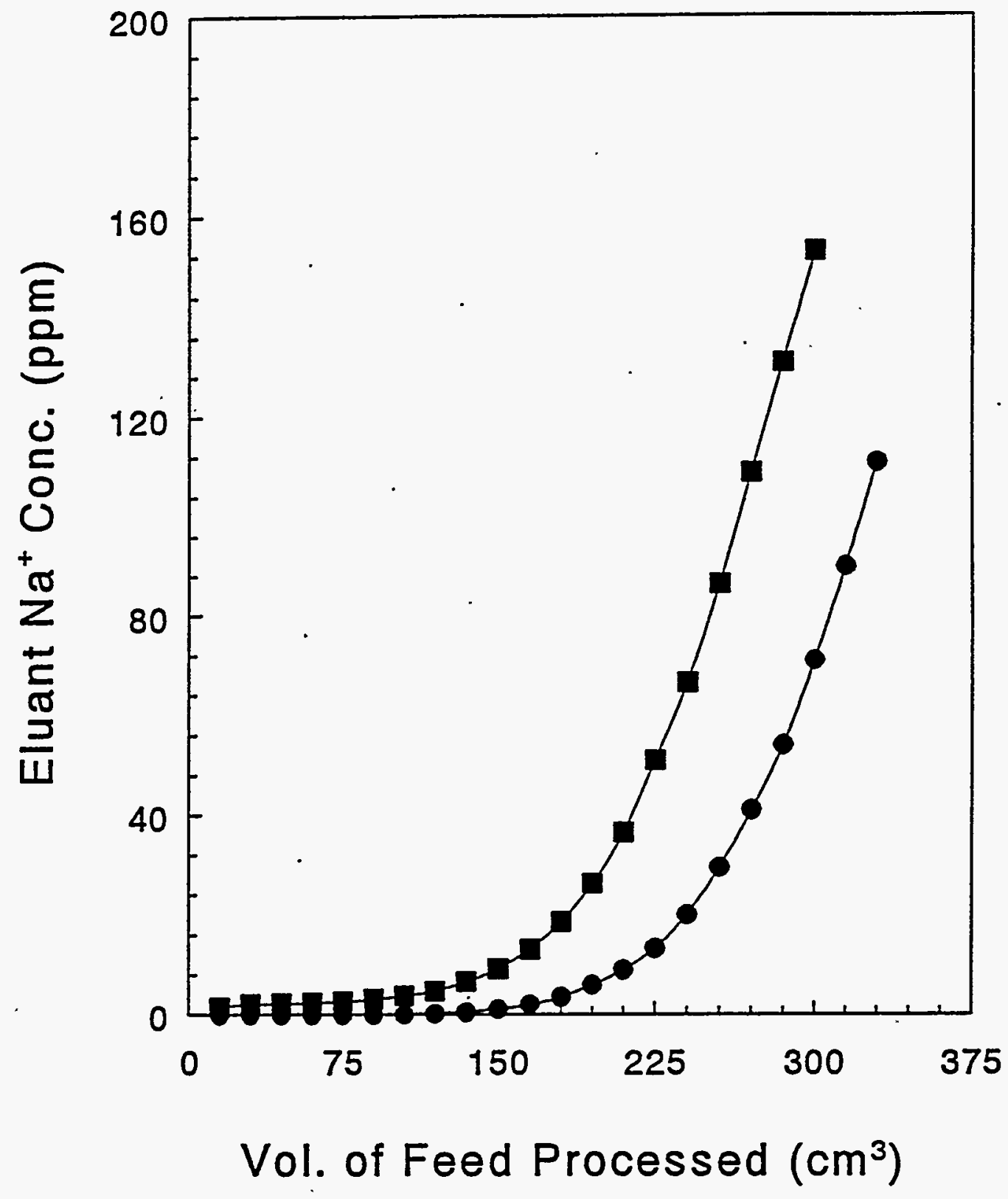

FIGURE A4. Sodium elution curves for Lewitat DN-KR ion exchange resin. O: Pre-degradation; a: post-degradation using $4 \mathrm{M} \mathrm{NaNO}$ and $1 \mathrm{M} \mathrm{NaOH}$. 


\section{APPENDIX B}

\section{$\beta$ COUNTER CALIBRATION}




\section{APPENDIX B}

\section{$\beta$ COUNTER CALIBRATION}

As mentioned in the Experimental Section, the cesium concentration in the catholyte, anolyte, resin acid wash solutions was measured using a LND Pancake $\alpha / \beta / \gamma$ detector with a Harwell 6000 Series 6255 Scaler Timer. Prior to each analysis, the counter was calibrated using the following five solutions containing $25,50,100,250$, and $500{ }^{137} \mathrm{Cs}$ in $5 \mathrm{ml}$ of deionized water. In Figure B1, a typical calibration curve for the analysis of the cesium concentration is shown. The data in Figure $\mathrm{B} 1$ indicates approximately $25 \%$ efficiency in the capture of the $\beta / \gamma$ radiation from ${ }^{137} \mathrm{Cs}$. It is also important to note from Figure B1, that measurement below $0.55 \mathrm{~Bq} / \mathrm{ml}$ is not possible. For this reason, the active cesium concentration in the feed was set at $4.44 \mathrm{KBq} / \mathrm{ml}$. In order to determine the effect of shielding of the sodium concentration on the $\beta / \gamma$ capture of the detector, solutions containing $5.55 \mathrm{~Bq} / \mathrm{ml}$ of ${ }^{137} \mathrm{Cs}$ and varying concentration of sodium nitrate (1 to $5 \mathrm{M}$ ) were prepared. and analyzed. Over the 5M range in the concentration of sodium, an attenuation of $10 \%$ in the signal was noted (which is caused by the absorption of the $\beta$ radiation in the salt layer). 


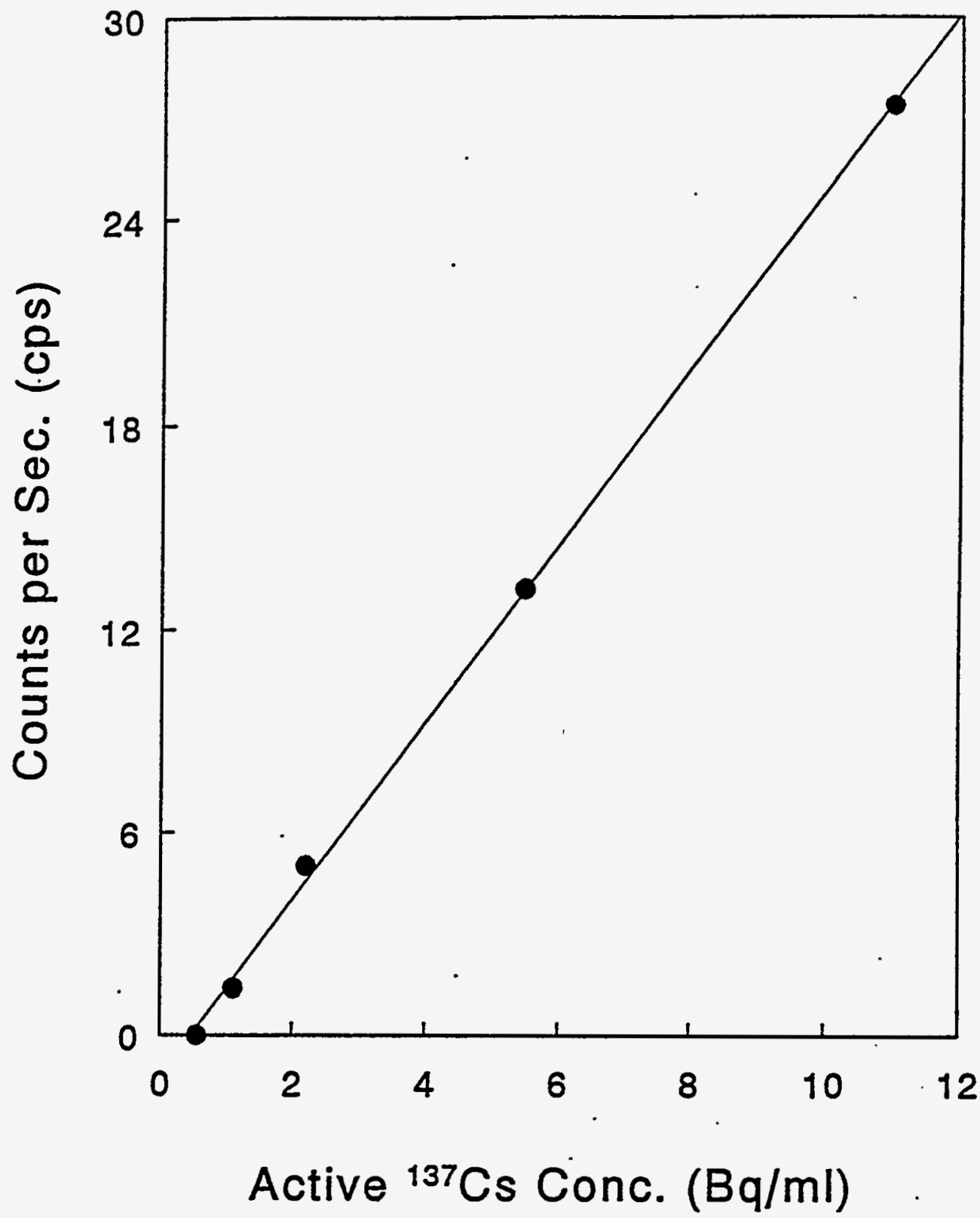

FIGURE B1. Typical Counter Calibration Curve for the Analysis of ${ }^{137}$ Cs. B. 2 
APPENDIX C

BATCH EOUILIBRIUM TESTS 


\section{APPENDIX C}

\section{BATCH EOUILIBRIUM TESTS}

The procedure for the determination of the batch equilibrium coefficients of the resins is the same as that already established at PNL (Carlson et al., 1990). The five different used to determine the batch equilibrium coefficients are: $0.5 \mathrm{M} \mathrm{NaNO}_{3}$ and $0.1 \mathrm{mCsNO}_{3}, 1 \mathrm{M} \mathrm{NaNO}_{3}$ and $0.1 \mathrm{mCsNO}_{3}$, 2.5 $\mathrm{M} \mathrm{NaNO}_{3}$ and $0.1 \mathrm{mCsNO}_{3}, 5 \mathrm{M} \mathrm{NaNO}_{3}$ and $0.1 \mathrm{mCsNO}_{3}$, and NCAW (see Table 3.1). The results of the Kd values obtained with Lewitat DN-KR and Resorcinol Formaldehyde resins are listed in Table C1.

TABLE C1. Kd Values for Lewitat DN-KR and Resorcinol Formaldehyde BSC-210 Resins.

\begin{tabular}{|c|c|c|}
\hline Resin & Feed Solution Na/Cs Ratio & Kd \\
\hline Lewitat DN-KR & 5000 & 227 \\
& 10000 & 97 \\
& 25000 & 112 \\
& 50000 & 62 \\
& NCAW & 76 \\
& & \\
Resorcinol Formaldehyde & 5000 & 1808 \\
& 10000 & 1247 \\
& 25000 & 710 \\
& 50000 & 449 \\
& NCAW & 458 \\
\hline
\end{tabular}

The $\mathrm{Kd}$ values in Table $\mathrm{C} 1$, indicate that the resorcinol formaldehyde resin outperforms the Lewitat DN-KR resin.

C. 1 